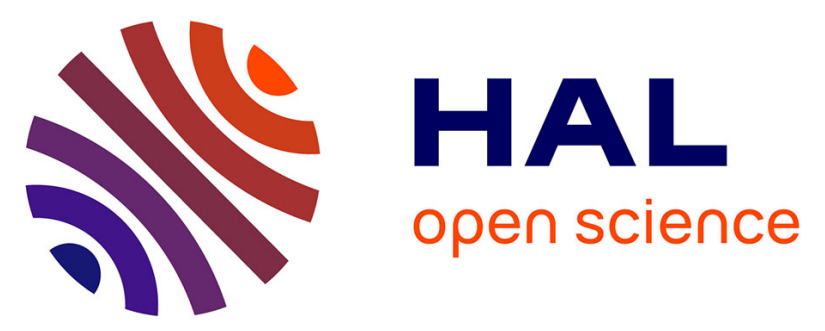

\title{
Organic matter deposition in the Ghadames Basin (Libya) during the Late Devonian-A multidisciplinary approach
}

Armelle Riboulleau, Amalia Spina, Marco Vecoli, Laurent Riquier, Melesio Quijada, Nicolas Tribovillard, Olivier Averbuch

\section{To cite this version:}

Armelle Riboulleau, Amalia Spina, Marco Vecoli, Laurent Riquier, Melesio Quijada, et al.. Organic matter deposition in the Ghadames Basin (Libya) during the Late Devonian-A multidisciplinary approach. Palaeogeography, Palaeoclimatology, Palaeoecology, 2018, 497, pp.37-51. 10.1016/j.palaeo.2018.02.004 . hal-01780055

\section{HAL Id: hal-01780055 https://hal.sorbonne-universite.fr/hal-01780055}

Submitted on 27 Apr 2018

HAL is a multi-disciplinary open access archive for the deposit and dissemination of scientific research documents, whether they are published or not. The documents may come from teaching and research institutions in France or abroad, or from public or private research centers.
L'archive ouverte pluridisciplinaire HAL, est destinée au dépôt et à la diffusion de documents scientifiques de niveau recherche, publiés ou non, émanant des établissements d'enseignement et de recherche français ou étrangers, des laboratoires publics ou privés. 
1 Organic matter deposition in the Ghadames Basin (Libya) during the Late Devonian-a multidisciplinary approach

3

\section{Abstract}

The organic rich deposits of Late Devonian age are the second most important petroleum source rocks in the Ghadames Basin (Libya). From available stratigraphy, the peak of organic matter deposition, corresponding to a level of radioactive shales easily recognized in gamma ray logs, occurred at the Frasnian-Famennian transition. The present study was focused on samples from borehole D1-26, located in the central part of the Ghadames Basin, belonging to the Aouinet Ouenine III and IV formations (Frasnian to Famennian). The mineral and organic content of the rocks were analyzed in order to determine the origin of organic matter accumulation and estimate if the organic matter enrichment could be related to

\footnotetext{
${ }^{1}$ Present address: Biostratigraphy Group, Exploration Technical Services Department, Saudi Aramco, Dhahran, Saudi Arabia
} 
the well-known Upper Kellwasser event. The results indicate that during the Frasnian, the planktonic primary productivity was moderate, but anoxic conditions reaching the euphotic zone were frequent and allowed efficient preservation of the organic matter. At the FrasnianFamennian transition, the deposition of the radioactive shales level can be related to a eustatic rise, which allowed incursion of nutrient-rich water in the basin, leading to increase in primary productivity and photic zone anoxia. During the Famennian, the conditions changed, associated with a relative sea level fall and/or a progradation of detrital sediments originating from the south. Photic zone anoxia was only episodic and plankton-derived organic matter was poorly preserved. Nevertheless, the important influx of organic matter of terrestrial origin allowed significant enrichment of the sediment in organic matter. Several indications suggest the radioactive shales interval could be coeval with the Upper Kellwasser level, nevertheless further stratigraphic work is needed to confirm this hypothesis.

\section{Keywords}

Biomarkers, palynofacies, major and trace elements, Frasnian-Famennian

\section{Introduction}

The Late Devonian was a period of extensive organic matter (OM) deposition along continental margins (Ulmishek and Klemme, 1990). The reasons for such widespread deposition of $\mathrm{OM}$ within oceanic realm is still a matter of discussion but a combination of several favorable factors has been proposed, including: (1) an overall rise of the sea level and a warmer climate favoring water stratification (Ulmishek and Klemme, 1990; Bond and Wignall, 2008; Riquier et al., 2010); (2) a tectonic context marked by the onset of the Variscan orogeny inducing both an increase of the nutrient supply from continents and the reduction of sea-water communications along the former Paleotethysian seaways (Tribovillard et al., 2004; Averbuch et al., 2005); (3) the development of root systems in terrestrial plants during this interval that may have also contributed to an increase in nutrient delivery to oceanic basins, promoting planktonic productivity (Algeo and Scheckler, 1998). The maximum convergence of these favoring conditions resulted in several anoxic events associated with biotic crises, the most famous of which, called the Kellwasser event, occurred at the Frasnian-Famennian boundary; it is characterized by the widespread deposition of two organic-rich levels respectively called the Lower and Upper Kellwasser levels (Buggisch, 1991; Joachimski and Buggisch, 1993; House, 2002; Bond et al., 2004; Racki, 2005; Riquier et al., 2006; Becker et al., 2012). Though considered as one of the major extinction events in 
Earth history, affecting both marine and continental faunas (see McGhee et al., 2013 for a recent review), the exact timing, causes and consequences of the Kellwasser event is still a matter of active research (Racki, 2005; Becker et al., 2016). The resultant massive organic carbon burial may have had a major impact on the global carbon cycle thereby enhancing a significant drop of the $\mathrm{CO}_{2}$ atmospheric content and a global cooling trend in Late Devonian times (Algeo et al., 1995; Joachimski and Buggisch, 2002; Godderis and Joachimski, 2004; Averbuch et al., 2005; Riquier et al., 2010).

North Africa is characterized by the presence of several large to giant petroleum systems associated with Paleozoic source rocks (Boote et al., 1998; Craig et al., 2008). In well logging, the organic-rich intervals are recognizable by their high radioactivity in gamma ray logs, and are qualified as "radioactive shales" or "hot shales". The dominant source rocks in North African petroleum systems are of Silurian age, in particular the Tanezzuft Formation in Algeria Tunisia and Libya, which base shows a characteristic hot shales interval (Boote et al., 1998; Craig et al., 2008). Organic-rich deposits of Late Devonian age are also widespread in North Africa and represent the second most important source rocks (Boote et al., 1998; Echikh, 1998; Lüning et al., 2003). From available stratigraphic correlations, the age of the Upper Devonian hot shales nevertheless varies from the early Frasnian to the early Famennian, from one basin to the other (Lüning et al., 2003). In the Ghadames Basin (Libya and Tunisia, Fig. 1), the Upper Devonian organic-rich level corresponds to a radioactive shales and limestones interval of late Frasnian age, sometimes referred to as the Cues limestones Horizon (Massa, 1988; Weyant and Massa, 1991). This interval well recognized in gamma ray logs (Weyant and Massa, 1991; Boote et al., 1998) could therefore be coeval to the Upper Kellwasser horizon (Joachimski and Buggisch, 1993; Bond et al., 2004). The two Kellwasser levels are well known in Morocco (Riquier et al., 2005), and Soua (2014) proposed that the two late Frasnian hot-shale intervals detected in South Tunisia were coeval to the Kellwasser levels.

This paper presents the results of a multidisciplinary study of a Frasnian-Famennian section in the Libyan part of the Ghadames Basin. The aim of the study was to determine the factors which favored OM deposition in this basin during the Late Devonian, and potentially relate it to the general context of the extensive Kellwasser environmental crisis. 


\section{Materials and methods}

2.1 Studied interval

This study is based on samples from borehole D1-26 $\left(30^{\circ} 29^{\prime} 21^{\prime \prime} \mathrm{N}, 10^{\circ} 46^{\prime} 28^{\prime \prime} \mathrm{E}\right)$ cored in 1960-61 by the Oasis Oil Company in Libya, in the central part of the Ghadames Basin (Fig. 1). Samples were taken from cores 6, 7 and 8 in the Aouinet Ouenine (or Awaynat Wanin) formations III and IV (AO III and AO IV, Fig. 2) and were labeled according to their depth in the core, originally given in feet. In the studied borehole, the AO III and AO IV formations mostly consist in grey to dark grey, finely laminated and micaceous shales to silty shales (Fig. 2). The upper part of the AO III Fm. is more calcareous and passes to alternating shales and fossiliferous limestones in the lower part of the AO IV Fm. (Fig. 2). This latter interval should correspond to the "Cues Limestone Horizon" and associated radioactive shales (Weyant and Massa, 1991). Sandy levels appear and become more abundant in the upper part of the AO IV Fm. (Fig. 2). Biostratigraphic constraints, based on palynomorphs and conodonts, and gamma ray correlations with other cores from the Ghadames Basin (Loboziak and Streel, 1989; Weyant and Massa, 1991; Spina et al., 2017), indicate that the samples from core 8 are of late Frasnian age, likely within the Palmatolepis rhenana conodont Zone (Streel, 2009), while those from core 6 are of late Famennian age (Fig. 2), likely within the Siphonodella praesulcata conodont Zone (Streel, 2009). Core 7 was collected in so-called radioactive shales (Massa, 2005, personal communication). This radioactive shale interval generally is considered of late Frasnian age (Massa, 1988; Boote et al., 1998). Nevertheless, Weyant and Massa (1991) analyzed the conodont content of two samples of unknown depth from core 7, and proposed an early Famennian age, in the Middle to Upper Palmatolepis triangularis Zone, or Palmatolepis crepida Zone.

\subsection{Palynology}

Eighteen core samples from the Aouinet-Ouenine III and IV formations (samples 7813 to $7081,2381.4 \mathrm{~m}$ to $2158.3 \mathrm{~m}$ ) were processed and analyzed. About 20-30 g of sample have been initially treated in hydrochloric acid (37\%), followed by digestion in hydrofluoric acid (50 \%) and by treatment in 30\% boiling hydrochloric acid to remove fluorosilicates. Residues were then subjected to density separation using zinc bromide solution in order to separate $\mathrm{OM}$ from heavy minerals. Finally, the organic-rich residues were sieved with acid resistant 50 and $15 \mu \mathrm{m}$ sieves. No oxidation by nitric acid was performed. A minimum of three palynological 
strew-slides were mounted for each sample using Eukitt as mounting medium. Palynological slides were examined using transmitted light microscopes, commonly with $\times 20$ (dry) and $\times 100$ (oil immersion) objectives. Palynological slides are stored in the collection of the UMR 8198 Evo-Eco-Paleo, Université de Lille-CNRS, Villeneuve d’Ascq (France). For palynofacies analysis, 300 particles were counted in each level, in order to estimate the proportions of the organic constituents. The organic constituents from D1-26 borehole were grouped according to Whitaker (1984) classification, modified to emphasize the organic components useful for palaeoenvironmental observations in the Devonian time span. The allochthonous fraction, of continental origin, includes the palynomaceral group (plant debris) and sporomorphs. The palynomaceral (PM) group is divided in PM1, orange to dark brown fragments, translucent, partially oxidized; PM2, cell-structured orange to dark-brown fragments, moderately oxidized; PM4, black opaque fragments, strongly oxidized. PM4 is the most stable palynomaceral and can be transported for a long distance before being degraded. Sporomorphs mostly correspond to cryptospores (Strother, 1991) and miospores (Steemans, 1999). The autochthonous fraction, of marine origin, comprises acritarchs, prasynophycean cysts, chitinozoans and amorphous organic matter (AOM). Acritarchs are organic-walled microfossils of uncertain biological affinity (Evitt, 1963), but mostly representing marine phytoplankton (Tappan, 1980; Martin, 1993; Colbath and Grenfell, 1995). In the Aouinet Ouenine sediments, prasynophycean cysts mainly correspond to Tasmanites (Tasmanaceae). This type of algal microfossil occurs in many marine facies from Cambrian to Miocene (Martín-Closas, 2003). Abundance of Tasmanites is often observed in marine (shelf and oceanic) organic-rich sediments (Tyson, 1995). Chitinozoans are organic-walled microfossil of uncertain affinity, but most probably representing marine microzooplankton (Paris and Nõlvak, 1999). AOM is the degradation product of benthic and pelagic cyanobacteria and sulfur bacteria in oxygen deficient environments. Being the most dissolvable OM, it can be preserved only in oxygen-deprived (suboxic to anoxic) environments, where it is not destroyed and biodegraded by consumers and decomposers or by the oxidizing processes (Hart, 1986). The quantity of this latter was established on unfiltered palynological residues, counting only particles larger than $50 \mu \mathrm{m}$.

\subsection{Bulk geochemistry}

Twelve samples in the $2158.3 \mathrm{~m}$ to $2381.4 \mathrm{~m}$ interval (samples 7081 to 7813 ) were analyzed for bulk geochemistry. Rock-Eval analyses were performed on $100 \mathrm{mg}$ of ground 
bulk rock at the Institut Français du Pétrole-Energies Nouvelles using a Rock-Eval 6 apparatus and standard analytical conditions (Behar et al., 2001). The main parameters obtained are total organic carbon content (TOC, in weight \%), Hydrogen index (HI, mg HC/g TOC), oxygen index (OI, mg $\mathrm{CO}_{2} / \mathrm{g}$ TOC), that are proportional to the $\mathrm{H} / \mathrm{C}$ and $\mathrm{O} / \mathrm{C}$ ratio of the kerogen, respectively, and Tmax, an indicator of OM maturity. The sulfur content was determined by elemental analysis of the sediment with a FlashEA 1112 Elemental Analyser (Thermo). The analysis was performed on 1.5 to $2 \mathrm{mg}$ of ground bulk rock added to approximately $5 \mathrm{mg}$ of vanadium pentoxide, used as a combustion catalyst. 2.5 -Bis(5-tertbutyl-benzoxazol-2-yl)thiophene (BBOT) was used as standard.

Major, minor, trace and rare earth elements (REE) concentrations were determined on ground bulk rock by inductively coupled plasma optical emission spectrometry (ICP-OES) and inductively coupled plasma mass spectrometry (ICP-MS), at Activation Laboratories Ltd. (Ancaster, Canada). Samples were mixed with a flux of lithium metaborate $\left(\mathrm{LiBO}_{2}\right)$ and lithium tetraborate $\left(\mathrm{Li}_{2} \mathrm{~B}_{4} \mathrm{O}_{7}\right)$, and fused in an induction furnace. Molten sample was immediately poured into a solution of $5 \%$ nitric acid $\left(\mathrm{HNO}_{3}\right)$ containing an internal standard, and mixed continuously until completely dissolved. The analytical accuracy and precision are found to be better than 1-2\% for major elements, 5\% for REE and 5-10\% for the other elements, as checked by international standards and analysis of replicate samples. The enrichment factors were calculated for trace elements often enriched biogenically or authigenically, as follows: $\mathrm{X}_{\mathrm{EF}}=\left[(\mathrm{X} / \mathrm{Al})_{\text {sample }} /(\mathrm{X} / \mathrm{Al})_{\mathrm{PAAS}}\right]$, where $\mathrm{X}$ and $\mathrm{Al}$ represent the weight $\%$ concentrations of element $\mathrm{X}$ and $\mathrm{Al}$, respectively. Samples were normalized using the Post Archean Average shale (PAAS) compositions (McLennan, 1989). An enrichment factor larger than 1 theoretically points to the enrichment of the element relative to the PAAS ; in other words it indicates whether an element is biogenically or authigenically enriched compared to what its concentration would be, if it were of merely clastic origin. Practically, enrichment factors are taken into consideration when they out pass the value of 3 . Full results are provided in Table S1. For calculation purpose, concentrations below the detection limit (Table S1) were taken as half the value of the detection limit.

\subsection{Biomarker analysis}

For biomarker analysis, rock fragments were extracted $(24 \mathrm{~h})$ with dichloromethane (DCM) in a refrigerator to remove possible contamination from the sample surface. The fragments were then crushed to extract the lipids from inside the rock. Ca. 30 g pulverized 
sample were extracted using a soxhlet apparatus with DCM (24 h). Elemental sulfur was removed by addition of activated copper to the recovered extracts. The solvent was removed by means of rotary evaporation and the residue re-dissolved in cyclohexane. The cyclohexane-soluble fraction (maltenes) was further separated by means of column chromatography. A mixture of standard compounds (2,2,4,4,6,8,8-heptamethylnonane, Dr Ehrenstorfer-GmbH; anthracene D10, Dr Ehrenstorfer-GmbH; nonadecan-2-one, SigmaAldrich) was added to the maltenes prior to fractionation. The aliphatic fraction was recovered from the maltenes by elution with cyclohexane on an activated silica column. Elution with a mixture of cyclohexane/DCM $(9 / 1, \mathrm{v} / \mathrm{v})$ recovered the aromatic fraction, after which the polar fraction was recovered by elution with $\mathrm{DCM} / \mathrm{MeOH}(1 / 1, \mathrm{v} / \mathrm{v})$. The aliphatic and aromatic fractions were analyzed by way of gas chromatography-mass spectrometry (GC-MS) using either a Trace GC 2000 gas chromatograph equipped with a DB5ht column (30 $\mathrm{m} \times 0.25 \mathrm{~mm}$ i.d.; $0.1 \mu \mathrm{m}$ film thickness). The oven temperature program was: $100{ }^{\circ} \mathrm{C}(1$ min) to $310{ }^{\circ} \mathrm{C}$ (held $16.5 \mathrm{~min}$ ) at $4{ }^{\circ} \mathrm{C} / \mathrm{min}$. Helium was used as carrier gas. The mass spectrometer conditions were as follow: ionization energy $70 \mathrm{eV}$ for electron ionization (EI) with a mass range m/z 50-700. Alternatively, samples were analyzed with a Perkin Elmer Clarus 680 GC equipped with a DB5MS ultra inert column $(30 \mathrm{~m} \times 0.25 \mathrm{~mm}$ i.d.; $0.25 \mu \mathrm{m}$ film thickness). The oven temperature program was: $60{ }^{\circ} \mathrm{C}(1 \mathrm{~min})$ to $100^{\circ} \mathrm{C}$ at $15^{\circ} \mathrm{C} / \mathrm{min}$, from $100^{\circ} \mathrm{C}$ to $200^{\circ} \mathrm{C}$ at $3^{\circ} \mathrm{C} / \mathrm{min}$, from $200{ }^{\circ} \mathrm{C}$ to $310^{\circ} \mathrm{C}$ (held $20 \mathrm{~min}$ ) at $4{ }^{\circ} \mathrm{C} / \mathrm{min}$. Helium was used as carrier gas. The mass spectrometer was operated at $70 \mathrm{eV}$ for electron ionization (EI) with a mass range $\mathrm{m} / \mathrm{z}$ 50-550 (full scan). Compounds were identified by comparison of mass spectra and elution order with published data.

\section{Results and interpretation}

\subsection{Palynofacies}

The palynofacies of the studied samples shows variable proportions of palynomorphs as well as AOM (Fig. 3). The palynofacies of the first levels from the AO III Fm. (base of core 8, samples 7813 to 7809 , Fig. 3) shows high abundances of acritarchs and prasynophycaean cysts (tasmanaceans) representing about $40 \%$ of the entire palynofacies. AOM is abundantly present in this interval, reaching up to $\sim 40 \%$ of the palynofacies. Partially oxidized palynomacerals (e.g. PM1+PM2) and sporomorphs are scarcely present. Chitinozoans are relatively abundant (5-7\%). In the overlying levels of the AO III Fm. (samples 7802 to 7780, 
Fig. 3), the palynofacies is dominated by the same marine elements but the proportion of acritarchs and tasmanaceans increases (up to $60 \%$ ) while the AOM content is reduced (0 to $10 \%$ ). At the base of AO IV Fm. (core 7, Fig.3), corresponding to the "radioactive shales", AOM in high proportion, acritarchs and prasynophycaean cysts characterize almost all the entire palynofacies. Sporomorphs and chitinozoans are very rare to absent. The acritarch fauna is well diversified in the samples from cores 8 and 7. A distinctive change in the palynofacies composition marks the uppermost levels (core 6) of AO IV Fm. (samples 7100 to 7081, Fig. 3). Strongly oxidized palynomacerals (PM4) and partially oxidized palynomacerals (PM1 + PM2) are abundant as well as well-preserved sporomorphs. This latter group reaches abundance around $35 \%$ in the levels close to the boundary with the overlying Tahara Fm. Microplankton here mainly consists of acritarchs (10 to $15 \%$ ). Tasmanites are uncommon $(\leq 10 \%)$. AOM and chitinozoans are very rare or absent.

\subsection{Bulk geochemistry}

\subsubsection{Organic matter and sulfur}

Total organic carbon (TOC) contents of the analyzed samples vary between 0.8 and $2.8 \%$ (average $1.75 \%$, Table 1). Tmax values range between 431 and $440{ }^{\circ} \mathrm{C}$. Average Tmax value in the uppermost samples is $435{ }^{\circ} \mathrm{C}$ indicating the beginning of the oil window. The average Tmax value is slightly higher in the samples from core $8\left(438^{\circ} \mathrm{C}\right)$ indicating a slightly higher thermal maturity.

HI values are between 60 and $319 \mathrm{mg} \mathrm{HC} / \mathrm{g}$ TOC (av. $132 \mathrm{mg} \mathrm{HC} / \mathrm{g}$ TOC) while OI values range between 0 and $47 \mathrm{mg} \mathrm{CO} / \mathrm{g}$ TOC. In a pseudo van Krevelen (HI-OI) as well as in the HI-Tmax diagram (Fig. 4A), the samples plot in the area of Type II-III OM. TOC/N atomic ratios vary between 14 and 44 (Table 1). In average, higher values are observed in the samples from core 6 (av. 38) than in samples from cores 7 and 8 (av. 18). Higher values of the $\mathrm{C} / \mathrm{N}$ ratio in the samples from the top of AO IV Fm. (samples 7100 to 7081) suggest a higher contribution from woody organic matter (Meyers, 1997), which is consistent with palynofacies observations.

The sulfur content of the sediment is relatively high, with an average value of $2.8 \%$. In a S vs TOC plot (Fig. 4B), most samples plot above the "normal marine" line (Berner, 1982), having a slope of 2 for the Devonian (Berner and Raiswell, 1983). It can be argued that this feature could result from a TOC loss upon maturation and petroleum expulsion, since 
Rock Eval production index (PI) values between 0.10 and 0.48 are compatible with oil expulsion (Table 1). Nevertheless, considering an initially doubled TOC values does not significantly change the S-TOC relationship as most samples would remain above this "normal marine" line (Fig. 4C). This S-TOC behavior is often considered as indicating deposition under strongly reducing to euxinic conditions (Leventhal, 1983).

\subsubsection{Productivity (Ba, $\mathrm{Ni}, \mathrm{Cu})$ and redox proxies (Mo, $\left.\mathrm{U}, \mathrm{V}, \mathrm{Ni}, \mathrm{Cu}, \mathrm{Zn}, \mathrm{Co}, \mathrm{Cr}, \mathrm{Ce} \mathrm{e}^{*}\right)$}

In order to be valid as productivity or redox proxies, elements must not be positively correlated with the Si (quartz) and/or Al (clay) content of the sediment. In the studied samples, $\mathrm{Si}$ and $\mathrm{Al}$ are negatively correlated, suggesting that the clay and silica content vary in opposite proportions. Most productivity and redox-sensitive elements in D1-26 samples are neither correlated with $\mathrm{Si}$ nor $\mathrm{Al}$, except for $\mathrm{Cr}$ which is positively correlated with $\mathrm{Al}(\mathrm{r}=$ $0.818, \mathrm{n}=12)$ and $\mathrm{Ba}$ which is positively correlated with $\mathrm{Si}(\mathrm{r}=0.933, \mathrm{n}=12)$. The latter correlation might indicate the presence of silica of biogenic origin. The average value of the $\mathrm{Ge} / \mathrm{Si}$ ratio of $8.110^{-6}$ however points for a mainly detrital origin of the silica in D1-26 samples, therefore corresponding to detrital quartz (Tribovillard, 2013). This indicates that $\mathrm{Cr}$ and $\mathrm{Ba}$ have a dominant detrital origin and cannot be considered as environmental proxies.

The average enrichment factors (EF) of the different elements which are not influenced by the detrital supply range between 0.5 and 3 (Fig. 5A), pointing for no significant authigenic enrichment in these sediments. In detail, most elements do not show a marked temporal trend except for molybdenum. The $\mathrm{Mo}_{\mathrm{EF}}$ curve shows values generally above 1 in the lowermost samples and a maximum value (22) in sample 7712. Above this sample, Mo is below the detection limit (Table S1) so that $\mathrm{Mo}_{\mathrm{EF}}$ values are below 1 . The cerium anomaly $\left(\mathrm{Ce}^{*}\right)$, though potentially influenced by changes in the detrital flux and sea level variations (Wilde et al., 1996), is negative for all the samples (average -0.048). The temporal variations of $\mathrm{Ce}^{*}$ are somehow opposite to Mo variations, the lowest values being observed in the lowermost samples, while higher values are observed in the upper part of the studied interval (Fig. 5B). Overall, these data point for only moderately reducing conditions during deposition of the two formations. The most reducing conditions, as indicated by the highest enrichment in molybdenum, are observed in the sample 7712, corresponding to the base of the organic-rich, radioactive clays. The AO III Fm. overall appears deposited in slightly more reducing conditions than the AO IV Fm. 


\subsubsection{Detrital proxies}

In addition to $\mathrm{Si}$ and $\mathrm{Al}$, elements mostly associated with detrital minerals comprise $\mathrm{K}$ (feldspar and/or illitic clay minerals), Ti (rutile, titanite or ilmenite), $\mathrm{Zr}$ (zircon) and rare earth elements (REE, which can be associated with several heavy minerals; Mongelli, 1995; Cullers and Podkovyrov, 2002). When normalized to the Al content, the concentration of these elements is a good indicator of changes in the detrital flux.

The geochemical composition of the lowermost five samples is relatively constant (Fig. 6). Only REE ratios show slight variations in this part (Fig. 6B). From sample 7780 upwards the geochemical composition is more variable, with overall higher element/Al ratios for Ti, Hf, Th and Zr (Fig. 6A). The REE profiles also are more variable as indicated by the $(\mathrm{La} / \mathrm{Lu})_{\mathrm{N}}$ and $(\mathrm{Gd} / \mathrm{Yb})_{\mathrm{N}}$ ratios (Fig. 6B). For major and trace elements a maximum in the Alnormalized content is observed in the sample 7087 (Fig. 6A). This sample is also characterized by a PAAS-normalized REE pattern markedly different from that of the other samples (Fig. 7).

Increase and variability of Al-normalized concentration of the different elements considered here mainly indicate a change from an argillaceous AO III Fm. to a more silty or more sandy AO IV Fm. The relative stability of REE patterns in the studied samples - except for sample 7087- suggests that these changes are mainly due to grain sorting rather than from changes in the origin of the detrital grains. In the case of sample 7087, the REE pattern of which is markedly different, the higher $\mathrm{Zr} / \mathrm{Al}$ and $\mathrm{Hf} / \mathrm{Al}$ ratios indicate a higher proportion of heavy minerals in the sediment. Such characteristics are observed in sediments deposited by turbidity currents (e.g. Riboulleau et al., 2014) and can be related to the increased proportion of sandy layers in the upper part of the AO IV Fm., reflecting a relative sea-level fall during the deposition of this formation (Massa, 1988; Carr, 2002).

\subsection{Biomarkers}

\subsubsection{Saturated fraction}

The saturate fraction is dominated by a series of linear alkanes ( $n$-alkanes). Hopanes, steranes, linear isoprenoids and cycloalkanes are present in lesser proportion. $n$-Alkanes range from $\mathrm{C}_{13}$ to $\mathrm{C}_{37}$ with a maximum in $\mathrm{C}_{16}$ or ${ }_{17}$ (Fig. 8A). The contribution from long chain $n$-alkanes is generally low, as indicated by the low value of the terrestrial to aquatic n-alkane ratio (TAR; Bourbonniere and Meyers, 1996; TAR values 0.06- 
0.52). Only the sample 7085 shows a higher contribution of long-chain alkanes (TAR $=0.74)$. No marked even or odd predominance is observed, as indicated by the CPI values close to 1 (Bray and Evans, 1961). The highest CPI values (1.2) are observed in the two uppermost samples (7087 and 7085). Linear isoprenoids range from $\mathrm{C}_{14}$ to $\mathrm{C}_{23}$, maximum in $\mathrm{C}_{19}$. The $\mathrm{Pr} / \mathrm{Ph}$ ratio ranges from 1.0 to 2.2. This highest value is obtained for the two uppermost samples.

The distribution of bicyclic and tricyclic terpenoids is similar in all the samples. Bicyclic sesquiterpenoids range from $\mathrm{C}_{14}$ to $\mathrm{C}_{16}$ and are dominated by ent-8$\beta(\mathrm{H})$ homodrimane followed by a $\mathrm{C}_{15}$ compound (Fig. $\left.8 \mathrm{~B}\right)$. Ent- $8 \beta(\mathrm{H})$ - drimane is also present in lesser amount. Three $\mathrm{C}_{19}$ tricyclic terpanes are also present in low abundance in all the samples. From its mass spectrum, the first eluting compound corresponds to a $13 \alpha$ (methyl)tricyclic terpane previously as described by Wang and Simoneit (1995). No other element from this series is apparently present. The following compounds correspond to compounds B and C of Greenwood and George (1999). A series of regular tricyclic terpanes (cheilantanes) ranging from $\mathrm{C}_{19}$ to $\mathrm{C}_{26}\left(\max \mathrm{C}_{23}\right)$ is also observed in all the samples (Fig. $8 \mathrm{C}$ ).

Hopanoids are present in all the samples but are relatively more abundant in the two uppermost samples. Hopanoids are dominated by a series of $\mathrm{C}_{27}$ to $\mathrm{C}_{34}$ regular $\alpha \beta$ hopanes (Fig. $8 \mathrm{C}$ ). $\beta \alpha$ Moretanes ranging from $\mathrm{C}_{29}$ to $\mathrm{C}_{34}$ are present in low abundance. In addition, several series of rearranged hopanes are observed: $\mathrm{C}_{24}$ and $\mathrm{C}_{26}$ 17,21-secohopanes (Lu et al., 2009), $\mathrm{C}_{29}$ and $\mathrm{C}_{30} 17 \alpha(\mathrm{H})$-diahopanes, $\mathrm{C}_{27}$ to $\mathrm{C}_{30} 18 \alpha(\mathrm{H})$-neohopanes (Ts series) and $\mathrm{C}_{29}-\mathrm{C}_{32}$ early eluting series (Moldowan et al., 1991; Farrimond and Telnæs, 1996). Norgammacerane and gammacerane are also detected in low amounts, mostly in the two uppermost samples.

Steroids are present in all the samples, but in very low abundance. They are slightly more abundant in the two uppermost samples. The distribution of compounds is comparable in all the samples with a few variations, and comprises the dia- and regular series, dominated by the $\mathrm{C}_{27}$ and $\mathrm{C}_{29}$ compounds (Fig. 8D, Table 2). Diasteroids are relatively less abundant in the two uppermost samples (Table 2). Methylsteranes and dinosterane isomers were not detected. Short chain steroids $C_{21}$ to $C_{23}$ are also observed in all the samples (Fig. 8D). They are generally present in relatively low abundance compared to the longer $\mathrm{C}_{27}-\mathrm{C}_{29}$ compounds. 


\subsubsection{Aromatic fraction}

This fraction is dominated by polycyclic aromatic hydrocarbons (PAHs) among which naphthalenes and phenanthrenes. Aromatic biomarkers mostly correspond to triaromatic steroids and arylisoprenoids.

Triaromatic steroids are observed in all the samples (not shown). They range from $\mathrm{C}_{20}$ to $\mathrm{C}_{28}$ and are dominated by the $\mathrm{C}_{26}$ to $\mathrm{C}_{28}$ compounds. Short chain compounds $\left(\mathrm{C}_{20}-\mathrm{C}_{22}\right)$ are however more abundant in the lower samples. The distribution is dominated by the $\mathrm{C}_{28}$ compounds for all the samples, however, the uppermost 2 samples show a higher contribution of the $\mathrm{C}_{26}$ compounds. 3-Methyl and 4-methyltriaromatic steroids are also present in minor proportion in all the samples, however no triaromatic dinosteroids were identified.

Aromatic compounds derived from hopanoids were detected in very low proportions in the two uppermost samples. They mostly correspond to a $\mathrm{C}_{24} \mathrm{ABCD}$-tetraaromatic hopanoid and des-E-D:C-friedo-25-norhopa-5,7,9-triene identified by Hauke et al. (1993). Cadalene is present in trace amounts in all the samples. Retene and the aromatic abietanoids were not detected.

A series of 2,3,6-trimethyl-arylisoprenoids ranging from $\mathrm{C}_{13}$ to $\mathrm{C}_{31}\left(\max \mathrm{C}_{18}\right)$ is observed in all the samples (Fig. 9). This series of compounds is well known as the product of degradation of isorenieratene (Requejo et al., 1992). A second series corresponding to 3,4,5trimethyl-arylisoprenoids is also observed (Fig. 9). These compounds derived from the degradation of the aromatic carotenoid palaerenieratene (Brown et al., 2000) are present in all the samples except the two uppermost samples (7087 and 7085). Isorenieratane was detected in low amount in all the samples while palaerenieratane is observed in the four lowest samples (7812 to 7712). Several other diagenetic/catagenetic products of isorenieratene previously described by Koopmans et al. (1996) were also detected in all the samples, where they show a similar distribution: a series of diaromatic isoprenoids with a biphenyl head characterized by a $\mathrm{m} / \mathrm{z} 237$ fragment ranging from $\mathrm{C}_{19}(\max )$ to $\mathrm{C}_{22}$, and $\mathrm{C}_{21}$ to $\mathrm{C}_{24}$ diaromatic compounds characterized by a m/z 133 fragment (compounds I to III, Fig. 9).

Alkylated di-, tri-, tetra-, and pentaaromatics are detected in abundance in all the samples. Naphtalene and methylated counterparts from $C_{1}$ to $C_{6}$ are present in all the samples. They are dominated by the $\mathrm{C}_{2}$ or $\mathrm{C}_{3}$ isomers. Phenanthrenes from $\mathrm{C}_{0}$ to $\mathrm{C}_{4}$ are observed in all the samples. Phenanthrene is the most abundant compound. Dibenzofurans are present in all the samples, but their proportion is higher in the uppermost two samples. They range from $\mathrm{C}_{0}$ to $\mathrm{C}_{2}$ and are dominated by the $\mathrm{C}_{1}$ isomers. Dibenzothiophenes (DBT) from $\mathrm{C}_{0}$ to $\mathrm{C}_{3}$ are observed in all the samples. Their relative abundance is however lower in the two uppermost 
samples. Their distribution is dominated by DBT or by 4-methyl-DBT. Fluoranthene, pyrene and methylated counterparts from $\mathrm{C}_{1}$ to $\mathrm{C}_{2}$ are detected in all the samples, however, their relative abundance is higher in the two uppermost samples. Triphenylene, chrysene their methylated counterparts from $\mathrm{C}_{1}$ to $\mathrm{C}_{4}$ are present in all the samples. The relative abundance of the $\mathrm{C}_{0}$ counterparts and relative distribution of methylated homologs however differs between the lower four and upper two samples. In particular, a large dominance of the nonmethylated counterparts is observed in the two uppermost samples. Isomer distribution ratios of selected PAHs are presented in Table 2.

Highly condensed PAH's such as benzo[e]pyrene, benzo[ghi]perylene or coronene are observed only in the uppermost two samples. They are not observed in the lowermost four samples, even by selective ion detection.

\section{Discussion}

\subsection{Organic matter maturity}

From the Rock-Eval Tmax values (Fig. 4A), the studied samples are located at the beginning of the oil window, with slightly higher maturity for samples from core 8 than for samples from core 6 . This range of maturity is also indicated by the color and state of preservation of the miospores, acritarchs and Tasmanites in the samples (Spina et al., 2017). Using average correlation between biomarker isomerization ratios and thermal maturity (Peters et al., 2005), the ratio obtained in the studied samples (Table 2) tends to indicate a higher maturity than Rock-Eval Tmax, samples from core 8 having reached the peak of oil generation while samples from core 6 would be slightly less mature. Methylphenanthrene isomerization ratios indicate even more maturity with calculated vitrinite reflectance values higher than $0.7 \%$ (Table 2). Hrouda (2004) previously observed a relatively poor correlation between molecular maturity indicators, vitrinite reflectance and Rock Eval in the Upper Devonian formations of the Ghadames Basin. Nevertheless, the relatively low maturity indicated by the Rock Eval data is supported by vitrinite reflectance measurements of 0.51 to 0.59 performed by Underdown et al. (2007) on the same depth interval. These maturities are also consistent with those obtained by Hrouda (2004) for Upper Devonian formations in nearby cores from the Ghadames Basin. This low maturity allows interpret further the biomarker distribution in the analyzed samples. 
4.2 Organic matter source

Based on palynofacies analysis, TOC/N ratio, and biomarker content, the $\mathrm{OM}$ in the Aouinet Ouenine Fm. shows a mixed contribution from continental and marine fractions. The palynofacies content and TOC/N ratio allow to clearly distinguish the lower samples (AO III Fm. and radioactive shales) dominated by marine elements from the upper part of AO IV Fm., where the contribution from continental OM is more significant. Such distinction is less obvious basing on the biomarkers, since terrestrial plant biomarkers are almost absent from the record. Terrestrial plants in the Late Devonian were mostly restricted to bryophytes and early tracheophytes (Taylor et al., 2009). Earliest plants have not been so far related to an abundance of diversified biomarkers (Versteegh and Riboulleau, 2010), nevertheless a few higher plant terpenoids were previously identified in Devonian rocks, including in sediments of the Ghadames Basin (Kashirtsev et al., 2010; Romero-Sarmiento et al., 2011). Devonian plants already possessed a waxy coating made of long chain $n$-alkanes, typical of plant cuticles (Eglinton and Hamilton, 1967; Versteegh and Riboulleau, 2010). The dominance of short chain $n$-alkanes $\left(<\mathrm{C}_{20}\right)$ in the samples is typical of sedimentary OM dominated by an autochthonous algal input (Gelpi et al., 1970). Nevertheless, the increased proportion of long $n$-alkanes in samples from core 6 , as indicated by the higher TAR values (Table 2), is consistent with an increased contribution of $\mathrm{OM}$ of terrestrial origin. Contribution from landderived OM in the two samples from core 6 (7087 and 7085) is also indicated by the PAH distribution, showing a high proportion of dibenzofurans, which have been related to dehydration of plant cellulose and polysaccharides (Sephton et al., 1999) and the contribution of unsubstituted highly condensed PAH such as coronene, which have been related to wildfires (Marynowski and Simoneit, 2009).

The sterane distribution, dominated by the $\mathrm{C}_{29}$ and $\mathrm{C}_{27}$ isomer (Table 2), is typical of OM of marine origin. Methylated counterparts, in particular 4-methyl isomers are generally of algal origin. Dinosteroids and 4-methyl steroids are often assigned to dinoflagellates and/or acritarchs. Though dinosteroids are absent from the extracts of D1-26 samples, the methylated steroids can be related to the marine algal input. In particular, several studies of Paleozoic rocks and petroleum have related these compounds to acritarchs (Moldowan et al., 1996; Moldowan and Talyzina, 1998).

Hopanoids and their diagenesis products, as well as drimane and homodrimane are related to bacterial inputs (Ourisson et al., 1979; Alexander et al., 1983). The sterane/hopane ratio is often used as an indicator of the proportion of bacterial biomass compared to the eukaryotic one. The highest values of this ratio are observed in the samples from the AO IV 
Fm. and therefore suggest higher contribution from eukaryotes in these samples, while a higher contribution from bacterial biomass is observed in the lowermost four samples.

Though their origin is still debated, tricyclic terpanes (cheilantanes) have been mostly related to the contribution from prasinophytes and in particular tasmanaceans (Aquino Neto et al., 1992; Dutta et al., 2006). This is consistent with the frequent observation of Tasmanites in the palynofacies of D1-26 samples (Fig. 3). High relative abundances of cheilantanes, indicated by the tricyclic/ $17 \alpha$ hopane ratio are observed in the four lower samples (7812 to 7712, Table 2). The upper two samples (7087 and 7085) show lower relative abundance of cheilantanes (Table 2), which can be related to the lower relative abundance of Tasmanites in the palynofacies (Fig. 3). Abundance of prasinophytes in general or of Tasmanites in particular, has also been related to an increase of the $\mathrm{C}_{28} / \mathrm{C}_{29}$ sterane ratio (Schwark and Empt, 2006). This is for instance the case at the Frasnian-Famennian transition in the famous Kowala section in Poland, where prasinophytes represent 80 to $90 \%$ of palynomorphs (Filipiak, 2002; Schwark and Empt, 2006). No relationship is observed between the $\mathrm{C}_{28} / \mathrm{C}_{29}$ sterane ratio and the relative abundance of Tasmanites in the palynofacies of D1-26 samples (Table 2, Fig. 3), which could be related to the fact that prasinophytes rarely account for more than $40 \%$ of palynomorphs in these samples.

\subsection{Redox conditions}

Isorenieratene is a pigment synthesized by green sulfur bacteria (Chlorobiaceae), obligate anaerobes requiring light and free sulfides for living (Liaaen-Jensen, 1978; Overmann, 2008). In particular, Chlorobiaceae have been observed in the water column of the Black Sea (Overmann et al., 1992). For this reason, the observation of isorenieratene derivatives in sediment extracts is often used as an indicator of photic zone anoxia (Summons and Powell, 1986). The source of palaerenieratene is unknown but several arguments suggest this compound originates from extinct organisms related to Chlorobiaceae (Hartgers et al., 1994). A recent review of the occurrence of palaerenieratane in oils and sediments confirms this compound is almost restricted to the Paleozoic (French et al., 2015). When present, palaerenieratane is often more abundant than isorenieratane (Requejo et al., 1992; Behrens et al., 1998; Clifford et al., 1998; Joachimski et al., 2001; Armstrong et al., 2009; Bushnev, 2009; Maslen et al., 2009; Racka et al., 2010; Marynowski et al., 2012; Melendez et al., 2013; Tulipani et al., 2015). Changes in the proportion of palaerenieratene vs. isorenieratene derivatives in relation to paleoenvironments are rarely reported in the literature. Nevertheless, in the Middle Devonian Keg River Fm., Behrens et al. (1998) observed that while both 
palaereniaratane and isorenieratane and their derivatives were present in transgressive facies, the regressive facies of this formation only showed the presence of isorenieratane and its derivatives.

The total concentration of isorenieratene and palaerenieratene derivatives in the extracts of D1-26 generally decreases up-section through the studied interval, with the maximum value observed in the lowermost sample and the minimum value in the uppermost sample (Fig. 10A). When plotted in the $\mathrm{Pr} / \mathrm{Ph}$ ratio versus the aryl isoprenoid ratio (AIR*) modified from Schwark and Frimmel (2004), the lowermost four samples from D1-26 plot in a sector of relatively persistent photic-zone anoxia and reducing sediment, while the uppermost two plot in an area of oxygenated sediment with more episodic photic-zone anoxia (Fig. 10C). Location of D1-26 samples in this plot are also consistent with previous observations in the Posidonia black shale, regarding relative sea-level variations (Schwark and Frimmel, 2004): samples from AO III Fm. and radioactive shales, deposited in a rising sea level plot in the "intermediate sea level" sector, while samples from the higher part of AO IV Fm., deposited in a regressive context, plot in the "high sea level" and "low sea level" sectors. The ratio of the 3,4,5-trimethyl- to 2,3,6-trimethyl-arylisoprenoids (palaerenieratene to isorenieratene derivatives ratio, PIR) slightly increases from the base to the middle part of the series and falls to 0 in the uppermost two samples (Fig. 10B). The disappearance of palaerenieratane and its derivatives in the regressive, highest part of AO IV Fm. is consistent with the previous observations of Behrens et al. (1998).

The abundance of prasinophytes in the palynofacies of D1-26 samples shows a good parallel with the relative abundance of isorenieratene and palaerenieratene and their derivatives in the extracts (Figs. 3, 10): present in significant proportion in AO III Fm. and the radioactive shales, they become minor in the upper part of AO IV Fm. This observation fully supports the proposition of Prauss (2007), who suggested that prasinophyte abundance in sediments is controlled by, and therefore is an indicator of, reducing conditions in the photic zone.

Based on redox-sensitive trace metal concentration, the studied Devonian sediments from borehole D1-26 appear deposited under mainly oxic conditions. This appears inconsistent with the occurrence of Chlorobiaceae biomarkers and of Tasmanites, in all the samples. The only sample showing enrichment in redox-sensitive trace metals is sample 7712, belonging to the very base of the radioactive shales. Its enrichment in uranium remains modest $(E F=2)$ while a more notable enrichment is observed for molybdenum $(E F=21)$. The contrasted enrichments in Mo and $\mathrm{U}$, respectively suggest molybdenum enrichment 
associated with redox cycling of manganese or iron oxyhydroxides, at the sediment waterinterface or within the water column (Algeo and Tribovillard, 2009). It means that the water column would have been regularly oxygenated but the redox-cline would have been lying at short distance beneath the sediment-water interface, thence an anoxic sediment. High enrichment in trace elements in the radioactive shales is reported by Weyant and Massa (1991), nevertheless these authors did not indicate from which boreholes or outcrops these data originated, moreover, no data are available for the rest of the Aouinet Ouenine group.

The discrepancy between molecular and inorganic redox proxies could result from a so-called "reservoir effect" (Algeo, 2004; Algeo and Lyons, 2006). When a basin is poorly connected with the open sea, scavenging of molybdenum and other redox-sensitive trace metals by the precipitation of authigenic minerals may overcome the inflow of these elements to the basin. This process results in the progressive depletion of these elements in the water column (Algeo, 2004; Algeo and Lyons, 2006). Sediments deposited below such depleted water column will not be enriched in trace elements, even if they are organic-rich and/or anoxic (Algeo, 2004; Tribovillard et al., 2008). During the Devonian, the North African domain was structured into several basins separated by topographic highs (Lüning et al., 2003; Guiraud et al., 2005; Wendt et al., 2006; Frizon de Lamotte et al., 2013). Poor connections of the bottom part of these basins with the open sea are suggested by the widespread deposition of organic-rich sediments in the various North African basins (Lüning et al., 2003; Wendt et al., 2006). Such configuration might therefore have favored progressive depletion of the water column in trace elements, leading to the poor enrichment observed in the studied samples from borehole D1-26.

\subsection{Organic matter deposition and relationships with the F/F events}

The studied samples from the Aouinet Ouenine Group where the TOC content was measured do not include the "radioactive shales" and are not very organic rich (Table 1). Nevertheless, the TOC values from 1 to $2 \%$ are consistent with previous studies of the Aouinet Ouenine Group in nearby boreholes (Hrouda, 2004).

The different methods used here indicate that in the Frasnian AO III Fm., OM mainly originates from an algo-bacterial biomass. The biomarker content and the significant contribution of Tasmanites in the palynofacies indicate that conditions in the sediment and water column were frequently reducing (Fig. 11A). The notable proportion of AOM in the palynofacies (Fig. 3) points to efficient OM preservation under reducing conditions. The moderate TOC values of the sediment despite recurrent anoxia, the notable proportion of 
land-derived $\mathrm{OM}$, and the abundant and well-diversified fauna of acritarchs in the palynofacies, nevertheless suggest that planktonic productivity was moderate (Fig. 11A). Consistent, Massa (1988) indicates that the facies in the AO III Fm. is confined and that the macrofauna are impoverished.

The palynofacies content and biomarkers in the radioactive shales from D1-26 borehole only moderately differ with those of the AO III Fm., indicating a dominantly algobacterial OM and frequently anoxic conditions in the sediment and water column (Fig. 11B,C). The high TOC content documented in the radioactive shales (Massa, 1988) is however a major difference with the AO III Fm., which, added to the low proportion of terrestrial $\mathrm{OM}$ in the palynofacies, suggests increased planktonic productivity and eutrophic conditions during deposition (Fig. 11B,C). Chitinozoans have been recently shown to be produced by relatively shelfal epiplanktonic organisms (Vandenbroucke et al., 2010). Their decreased abundance in the palynofacies of the radioactive shales compared to AO III Fm. as well as the absence of sporomorphs are consistent with a more pelagic setting, and therefore an increased sea level (Fig. 11B,C).

Eutrophication leading to the deposition of the radioactive shales could have resulted from the input of land-derived nutrients in the basin (Algeo et al., 1995; Averbuch et al., 2005), however, the Late Devonian was dominantly a period of subsidence and not of uplift around the Ghadames Basin (Craig et al., 2008). Moreover, though the detrital elements suggest a change in the detrital flux between AO III and AO IV formations (Fig. 6), this change appears to be modest (Fig. 7) and is already observed in sample 7780, several meters below the radioactive shales. The present data therefore do not support an increased supply of land-derived nutrients in the Ghadames Basin. Since depositional conditions were already reducing in the Ghadames Basin during the deposition of AO III Fm. (Fig. 11A), nutrients could either have been recycled from the water-column by more frequent water-column mixing (Murphy et al., 2000), or originate from incursions of nutrient-rich water from the Paleotethys. On the one hand, we do not have arguments regarding more frequent watercolumn mixing. On the other hand, incursions of water from the open sea were likely favored by the sea level rise, and are supported by the Mo/Al ratio of the samples (Fig. 5). As previously discussed, the redox-sensitive trace elements suggest that the water column of the Ghadames Basin was relatively depleted in dissolved trace metals during deposition of AO III Fm. The enrichment in molybdenum observed in sample 7712 was therefore only possible because of Mo inputs, refuelled by the ingression of « new » sea water into the basin (Algeo, 2004; Algeo and Lyons, 2006). 
The ambiguity on the age of samples from core 7 compels us to consider several scenarios relating the radioactive shales with the Frasnian-Famennian transition events. Massa (1988; pers. comm., 2005) suggested that the radioactive shales were of latest Frasnian age. If so, the radioactive shales of the Ghadames Basin might be equivalent to the Upper Kellwasser level. The two Kellwasser levels are well known in Morocco (Riquier et al., 2005), and the Frasnian radioactive shales have been related to the upper Kellwasser level in the Berkhine area in Algeria (Lüning et al., 2004) and in southern Tunisia (Soua, 2014). The deposition of the upper Kellwasser level and of the radioactive shales from the Ghadames Basin were both related to a Late Frasnian second-order sea-level high-stand (Carr, 2002; Chen and Tucker, 2003; Dardour et al., 2004; Bond and Wignall, 2008). The eutrophication and possible development of more reducing conditions during the Upper Kellwasser event could result from the incursion of nutrient-rich and anoxic waters into the Ghadames Basin originating from the Paleotethys (Fig. 11B). This option would give support to the scenarios relating the deposition of the Kellwasser level to widespread oceanic eutrophication and development of anoxia in marginal basins (Joachimski and Buggisch, 1993; Bond et al., 2004; Averbuch et al., 2005; Riquier et al., 2006; Carmichael et al., 2014).

Alternately, if the radioactive shales were of early Famennian age (Weyant and Massa, 1991), their deposition could be related to the early Famennian sea-level rise documented in several basins (Sandberg et al., 2002; Haq and Schutter, 2008). Though sea-level variations around the Frasnian-Famennian are still a matter of discussion (Bond and Wignall, 2008), this could correspond to T-R cycle IIe of Johnson et al. (1985). Deposition of black shales in basinal settings during the early Famennian have been described in Poland, France, Morocco and Eastern North America (Wendt and Belka, 1991; Bond et al., 2004; Schieber and Lazar, 2004; Riquier et al., 2005) and may be related to this sea-level rise. For instance, in the Illinois Basin, the lowermost deposits of Famennian age in the New Albany shales show a more basinal facies and more eutrophic conditions than late Frasnian deposits (de la Rue et al., 2007). The radioactive shales would then correspond to a model of « transgressive black shales ", where connection with the open sea allows the entrance of nutrient-rich water and eutrophication (Fig. 11C), as observed in the Cariaco Basin (Venezuela) tuned to Quaternary sea-level oscillations (Peterson et al., 2000).

In addition to its well known $\delta^{13} \mathrm{C}$ excursion (Joachimski and Buggisch, 1993), recent studies indicate the Upper Kellwasser level could be characterized by molecular signatures: increase of the $\mathrm{C}_{28} / \mathrm{C}_{29}$ sterane ratio (Schwark and Empt, 2006) related to the prominence of prasinophytes and low values of the hopane/sterane ratio, indicating high relative input of 
eukaryotes (Haddad et al., 2016). The radioactive shales of borehole D1-26 show a slight decrease of the $\mathrm{C}_{28} / \mathrm{C}_{29}$ sterane ratio compared to the other samples (Table 2). The hopane/sterane ratio is lower in the radioactive shales than in the samples from the AO IV formation (Table 2). Nevertheless, similarly low hopane/sterane ratios are observed in the samples from AO III Fm. (Table 2). None of these parameters therefore allows clarify the ambiguity on the age of samples from core 7.

The highest part of AO IV Fm. is characterized by a change in sedimentary facies compared to underlying levels. The proportion of sand increases (Fig. 2, 6), indicating a more proximal depositional setting. This lithological evolution is related to a third- or second-order relative sea-level fall (Carr, 2002; Dardour et al., 2004; Fig. 11D). Consistent, the OM content changes and is dominated by land-derived material (Fig. 3). The lower sea-level and restricted conditions could have favored oligotrophic conditions in the Ghadames Basin (Fig. 11D). Palynofacies and biomarkers point to relatively oxidative conditions in the sediment (Fig. 11D), with only episodic photic zone anoxia. Though conditions were less prone to OM preservation, the highest part of the AO IV Fm. shows TOC values comparable to the AO III Fm. OM enrichment in this interval therefore appears to be related to an increased contribution of relatively resistant and less oil-prone terrestrial OM (Fig. 11D).

\section{Conclusions}

The multidisciplinary analysis of the Frasnian-Famennian Aouinet Ouenine III and IV formations in borehole D1-26, located in the Ghadames Basin (Libya) allowed to better understand the factors of OM enrichment in this important petroleum system. Our data indicate that during the Late Frasnian the Ghadames Basin was restricted and subject to frequent episodes of photic-zone anoxia. These conditions allowed a good preservation of OM derived from a moderate phytoplanktonic productivity. The beginning of OA IV Fm. is marked by the deposition of a radioactive shale interval, well known in core loggings of the Ghadames Basin, and corresponds to an episode of increased primary productivity and photiczone anoxia. Though ambiguity remains on the exact age of this radioactive shale interval, our data suggest eutrophication was favored by the entrance of nutrient-rich waters into the Ghadames Basin. The upper part of OA IV Fm. is marked by a facies change associated with the Famennian regression. Photic zone anoxia was less frequent but the sediment is still organic-rich because of increased delivery of terrestrial OM. 
The Late Devonian was a period of important changes in the carbon cycle marked by several episodes of oceanic anoxia and biotic crisis. While detailed and high-resolution studies of Late Devonian events in European, Asian and North-American successions are numerous, similar studies in North Gondwana remain rare and are mainly restricted to Morocco and Algeria, where the sediments present relatively proximal depositional facies. The present study demonstrates that the Ghadames Basin, in addition to its important petroleum interest, contains a rich sedimentary succession prone to future high-resolution studies of the Late Devonian events in North Gondwana.

\section{Acknowledgments}

This article is dedicated to the memory of Dominique Massa who provided the samples and supported research in the Paleozoic of North Africa. Jonhatan Redfern (University of Manchester) is acknowledged for providing detailed information on D1-26 borehole. This is a contribution to the project "The terrestrialization process: modeling complex interaction at the biosphere-geosphere interface" financially supported by the INSU ECLIPSE program, and the ANR TERRES project (ANR-10-BLAN-0607). Université de Lille is acknowledged for a 12-month postdoctoral grant awarded to A. Spina. Nicolas Visez and Sylvie Gosselin (PC2A, Université de Lille) are acknowledged for GC-MS injections. Thomas Algeo, Grzegorz Racki and an anonymous reviewer are acknowledged for constructive comments on the first version of this manuscript.

\section{Literature}

Alexander, R., Kagi, R., Noble, R. (1983) Identification of the bicyclic sesquiterpenes drimane and eudesmane in petroleum. Journal of the Chemical Society, Chemical Communications, 5, 226-228.

Algeo, T.J. (2004) Can marine anoxic events draw down the trace element inventory of seawater? Geology, 32, 12, 1057.

Algeo, T.J., Berner, R.A., Maynard, J.B., Scheckler, S.E. (1995) Late Devonian oceanic anoxic events and biotic crises: "rooted" in the evolution of vascular land plants? GSA Today, $\mathbf{5}, 3,45,64-66$. 
Algeo, T.J., Lyons, T.W. (2006) Mo-total organic carbon covariation in modern anoxic marine environments: Implications for analysis of paleoredox and paleohydrographic conditions. Paleoceanography, 21, 1, PA1016.

Algeo, T.J., Scheckler, S.E. (1998) Terrestrial-marine teleconnections in the Devonian: links between the evolution of land plants, weathering processes, and marine anoxic events. Philosophical Transactions of the Royal Society B: Biological Sciences, 353, 1365, 113-130. Algeo, T.J., Tribovillard, N. (2009) Environmental analysis of paleoceanographic systems based on molybdenum-uranium covariation. Chemical Geology, 268, 3-4, 211-225. Aquino Neto, F.R., Trigüis, J., Azevedo, D.A., Rodriques, R., Simoneit, B.R.T. (1992) Organic geochemistry of geographically unrelated tasmanites. Organic Geochemistry, 18, 6, 791-803.

Armstrong, H.A., Abbott, G.D., Turner, B.R., Makhlouf, I.M., Muhammad, A.B., Pedentchouk, N., Peters, H. (2009) Black shale deposition in an Upper Ordovician-Silurian permanently stratified, peri-glacial basin, southern Jordan. Organic-Carbon-Rich Sediments through the Phanerozoic: Processes, Progress, and Perspectives, 273, 3, 368-377. Averbuch, O., Tribovillard, N., Devleeschouwer, X., Riquier, L., Mistiaen, B., Van VlietLanoe, B. (2005) Mountain building-enhanced continental weathering and organic carbon burial as major causes for climatic cooling at the Frasnian-Famennian boundary (c. $376 \mathrm{Ma})$ ? Terra Nova, 17, 1, 25-34.

Becker, R.T., Gradstein, F.M., Hammer, O. (2012) Chapter 22 - The Devonian Period. The Geologic Time Scale, Elsevier, Boston, pp. 559-601.

Becker, R.T., Königshof, P., Brett, C.E. (2016) Devonian climate, sea level and evolutionary events. Geological Society of London, $481 \mathrm{p}$.

Behar, F., Beaumont, V., De B. Penteado, H.L. (2001) Technologie Rock-Eval 6 : performances et développements. Oil \& Gas Science and Technology - Rev. IFP, 56, 2, 111134.

Behrens, A., Wilkes, H., Schaeffer, P., Clegg, H., Albrecht, P. (1998) Molecular characterization of organic matter in sediments from the Keg River formation (Elk Point group), western Canada sedimentary basin. Organic Geochemistry, 29, 8, 1905-1920. Berner, R.A. (1982) Burial of organic carbon and pyrite sulfur in the modern ocean: its geochemical and environmental significance. American Journal of Science, 282, 451-473. Berner, R.A., Raiswell, R. (1983) Burial of organic carbon and pyrite sulfur in sediments over Phanerozoic time: a new theory. Geochimica et Cosmochimica Acta, 47, 855-862. 
Bond, D., Wignall, P.B., Racki, G. (2004) Extent and duration of marine anoxia during the Frasnian-Famennian (Late Devonian) mass extinction in Poland, Germany, Austria and France. Geological Magazine, 141, 2, 173-193.

Bond, D.P.G., Wignall, P.B. (2008) The role of sea-level change and marine anoxia in the Frasnian-Famennian (Late Devonian) mass extinction. Palaeogeography, Palaeoclimatology, Palaeoecology, 263, 3, 107-118.

Boote, D.R.D., Clark-Lowes, D.D., Traut, M.W. (1998) Palaeozoic petroleum systems of North Africa. Geological Society, London, Special Publications, 132, 1, 7.

Bourbonniere, R.A., Meyers, P.A. (1996) Sedimentary geolipid records of historical changes in the watersheds and productivities of Lakes Ontario and Erie. Limnology and Oceanography, 41, 2, 352-359.

Bray, E.E., Evans, E.D. (1961) Distribution of $n$-paraffins as a clue to recognition of source beds. Geochimica et Cosmochimica Acta, 22, 2-15.

Brown, E.T., Le Callonnec, L., German, C.R. (2000) Geochemical cycling of redox-sensitive metals in sediments from Lake Malawi: a diagnostic paleotracer for episodic changes in mixing depth. Geochimica et Cosmochimica Acta, 64, 20, 3515-3523.

Buggisch, W. (1991) The global Frasnian-Famennian»Kellwasser Event«. Geologische Rundschau, 80, 1, 49-72.

Bushnev, D. (2009) Organic matter of the Ukhta domanik. Doklady Earth Sciences, 426, 4, $1531-8354$.

Canaple, J. (1963) Synthèse régionale du sud-tunisien. Corrélations entre les forages BS1OS1-SN1-DN1-MG1-D1.26. Compagnie Franco-tunisienne des pétroles,. Carmichael, S.K., Waters, J.A., Suttner, T.J., Kido, E., DeReuil, A.A. (2014) A new model for the Kellwasser Anoxia Events (Late Devonian): Shallow water anoxia in an open oceanic setting in the Central Asian Orogenic Belt. Palaeogeography, Palaeoclimatology, Palaeoecology, 399, 394-403.

Carr, I.D. (2002) Second-order sequence stratigraphy of the Palaeozoic of North Africa. Journal of Petroleum Geology, 25, 3, 259-280.

Chen, D., Tucker, M.E. (2003) The Frasnian-Famennian mass extinction: insights from highresolution sequence stratigraphy and cyclostratigraphy in South China. Palaeogeography, Palaeoclimatology, Palaeoecology, 193, 1, 87-111.

Clifford, D.J., Clayton, J.L., Sinninghe Damsté, J.S. (1998) 2,3,6-/3,4,5-Trimethyl substituted diaryl carotenoid derivatives (Chlorobiaceae) in petroleums of the Belarussian Pripyat River Basin. Organic Geochemistry, 29, 5-7, 1253-1267. 
Colbath, G.K., Grenfell, H.R. (1995) Review of biological affinities of Paleozoic acidresistant, organic-walled eukaryotic algal microfossils (including "acritarchs"). Review of Palaeobotany and Palynology, 86, 3, 287-314.

Craig, J., Rizzi, C., Said, F., Thusu, B., Lüning, S., Asbali, A.I., Keeley, M.L., Bell, J.F., Durham, M.J., Eales, M.H., et al. (2008) Structural styles and prospectivity in the Precambrian and Palaeozoic hydrocarbon systems of North Africa. In : Salem, M.J., Oun, K.M., Essed, A.S., (eds.). The Geology of East Libya, Vol. IV, pp. 51-122.

Cullers, R.L., Podkovyrov, V.N. (2002) The source and origin of terrigenous sedimentary rocks in the Mesoproterozoic Ui group, southeastern Russia. Precambrian Research, 117, 3 $4,157-183$

Dardour, A.M., Boote, D.R.D., Baird, A.W. (2004) Stratigraphic controls on Palaeozoic petroleum systems, Ghadames Basin, Libya. Journal of Petroleum Geology, 27, 2, 141-162. Dutta, S., Greenwood, P.F., Brocke, R., Schaefer, R.G., Mann, U. (2006) New insights into the relationship between Tasmanites and tricyclic terpenoids. Organic Geochemistry, 37, 1, $117-127$.

Echikh, K. (1998) Geology and hydrocarbon occurrences in the Ghadames Basin, Algeria, Tunisia, Libya. Geological Society, London, Special Publications, 132, 1, 109.

Eglinton, G., Hamilton, R.J. (1967) Leaf epicuticular waxes. Science, 156, 3780, 1322-1335. Evitt, W.R. (1963) A discussion and proposals concerning fossil dinoflagellates, hystrichospheres, and acritarchs, I. Proceedings of the National Academy of Sciences, 49, 2, $158-164$.

Farrimond, P., Telnæs, N. (1996) Three series of rearranged hopanes in Toarcian sediments (northern Italy). Organic Geochemistry, 25, 3-4, 165-177.

Filipiak, P. (2002) Palynofacies around the Frasnian/Famennian boundary in the Holy Cross Mountains, southern Poland. Palaeogeography, Palaeoclimatology, Palaeoecology, 181, 1-3, 313-324.

French, K.L., Rocher, D., Zumberge, J.E., Summons, R.E. (2015) Assessing the distribution of sedimentary $\mathrm{C}_{40}$ carotenoids through time. Geobiology, 13, 2, 139-151.

Frizon de Lamotte, D., Tavakoli-Shirazi, S., Leturmy, P., Averbuch, O., Mouchot, N., Raulin, C., Leparmentier, F., Blanpied, C., Ringenbach, J.-C. (2013) Evidence for Late Devonian vertical movements and extensional deformation in northern Africa and Arabia: Integration in the geodynamics of the Devonian world. Tectonics, 32, 2, 107-122.

Gelpi, E., Schneider, H., Mann, J., Oro, J. (1970) Hydrocarbons of geochemical significance in microscopic algae. Phytochemistry, 9, 3, 603-612. 
Godderis, Y., Joachimski, M.M. (2004) Global change in the Late Devonian: modelling the Frasnian-Famennian short-term carbon isotope excursions. Palaeogeography, Palaeoclimatology, Palaeoecology, 202, 3-4, 309-329.

Greenwood, P.F., George, S.C. (1999) Mass spectral characteristics of $\mathrm{C}_{19}$ and $\mathrm{C}_{20}$ tricyclic terpanes detected in Latrobe Tasmanite oil shale. European Mass Spectrometry, 5, 3, $221-$ 230.

Guiraud, R., Bosworth, W., Thierry, J., Delplanque, A. (2005) Phanerozoic geological evolution of Northern and Central Africa: An overview. Phanerozoic Evolution of Africa, 43, $1,83-143$.

Haddad, E.E., Tuite, M.L., Martinez, A.M., Williford, K., Boyer, D.L., Droser, M.L., Love, G.D. (2016) Lipid biomarker stratigraphic records through the Late Devonian

Frasnian/Famennian boundary: Comparison of high- and low-latitude epicontinental marine settings. Organic Geochemistry, 98, 38-53.

Haq, B.U., Schutter, S.R. (2008) A chronology of Paleozoic sea-level changes. Science, 322, 5898,64 .

Hart, G.F. (1986) Origin and classification of organic matter in clastic systems. Palynology, 10, 1,1 .

Hartgers, W.A., Sinninghe Damsté, J.S., Requejo, A.G., Allan, J., Hayes, J.M., Ling, Y., Xie, T.-M., Primack, J., de Leeuw, J.W. (1994) A molecular and carbon isotopic study towards the origin and diagenetic fate of diaromatic carotenoids. Organic Geochemistry, 22, 3, 703-725. Hauke, V., Wehrung, P., Hussler, G., Trendel, J.M., Albrecht, P., Riva, A., Connan, J. (1993) Rearranged des-E-hopanoid hydrocarbons in sediments and petroleum. Organic Geochemistry, 20, 3, 415-423.

House, M.R. (2002) Strength, timing, setting and cause of mid-Palaeozoic extinctions. Palaeogeography, Palaeoclimatology, Palaeoecology, 181, 1-3, 5-25.

Hrouda, M. (2004) The hydrocarbon source potential of the Palaeozoic rocks of the Ghadames Basin, NW Libya. Newcastle University.

Joachimski, M.M., Buggisch, W. (1993) Anoxic events in the late Frasnian-Causes of the Frasnian-Famennian faunal crisis? Geology, 21, 8, 675-678.

Joachimski, M.M., Buggisch, W. (2002) Conodont apatite $\delta^{18} \mathrm{O}$ signatures indicate climatic cooling as a trigger of the Late Devonian mass extinction. Geology, 30, 8, 711. Joachimski, M.M., Ostertag-Henning, C., Pancost, R.D., Strauss, H., Freeman, K.H., Littke, R., Sinninghe Damsté, J.S., Racki, G. (2001) Water column anoxia, enhanced productivity 
and concomitant changes in $\delta^{13} \mathrm{C}$ and $\delta^{34} \mathrm{~S}$ across the Frasnian-Famennian boundary (Kowala - Holy Cross Mountains/Poland). Chemical Geology, 175, 1-2, 109-131. Johnson, J.G., Klapper, G., Sandberg, C.A. (1985) Devonian eustatic fluctuations in Euramerica. GSA Bulletin, 96, 5, 567-587.

Kashirtsev, V.A., Moskvin, V.I., Fomin, A.N., Chalaya, O.N. (2010) Terpanes and steranes in coals of different genetic types in Siberia. Russian Geology and Geophysics, 51, 4, 404-411. Koopmans, M.P., Köster, J., Van Kaam-Peters, H.M.E., Kenig, F., Schouten, S., Hartgers, W.A., de Leeuw, J.W., Sinninghe Damsté, J.S. (1996) Diagenetic and catagenetic products of isorenieratene: Molecular indicators for photic zone anoxia. Geochimica et Cosmochimica Acta, 60, 22, 4467-4496.

Leventhal, J.S. (1983) An interpretation of carbon and sulfur relationships in Black Sea sediments as indicators of environments of deposition. Geochimica et Cosmochimica Acta, 47, 133-137.

Liaaen-Jensen, S. (1978) Marine carotenoids. In : Scheuer, P.J., (ed.). Marine Natural Products, Chemical and Biological Perspectives, Academic Press, pp. 1-73.

Loboziak, S., Streel, M. (1989) Middle-upper Devonian miospores from the Ghadamis Basin (Tunisia-Libya): Systematics and stratigraphy. Review of Palaeobotany and Palynology, 58, 2-4, 173-196.

Lu, H., Chen, T., Grice, K., Greenwood, P., Peng, P., Sheng, G. (2009) Distribution and significance of novel low molecular weight sterenes in an immature evaporitic sediment from the Jinxian Sag, North China. Organic Geochemistry, 40, 8, 902-911.

Lüning, S., Adamson, K., Craig, J. (2003) Frasnian organic-rich shales in North Africa: regional distribution and depositional model. Geological Society, London, Special Publications, 207, 1, 165.

Lüning, S., Wendt, J., Belka, Z., Kaufmann, B. (2004) Temporal-spatial reconstruction of the early Frasnian (Late Devonian) anoxia in NW Africa: new field data from the Ahnet Basin (Algeria). Sedimentary Geology, 163, 3, 237-264.

Martin, F. (1993) Acritarchs: a review. Biological Reviews, 68, 4, 475-537.

Martín-Closas, C. (2003) The fossil record and evolution of freshwater plants: A review. Geologica Acta, 1, 4, 315-338.

Marynowski, L., Simoneit, B.R.T. (2009) Widespread Upper Triassic to Lower Jurassic wildfire records from Poland: evidence from charcoal and pyrolytic polycyclic aromatic hydrocarbons. Palaios, 24, 12, 785-798. 
Marynowski, L., Zatoń, M., Rakociński, M., Filipiak, P., Kurkiewicz, S., Pearce, T.J. (2012) Deciphering the upper Famennian Hangenberg Black Shale depositional environments based on multi-proxy record. Palaeogeography, Palaeoclimatology, Palaeoecology, 346, 66-86. Maslen, E., Grice, K., Gale, J.D., Hallmann, C., Horsfield, B. (2009) Crocetane: A potential marker of photic zone euxinia in thermally mature sediments and crude oils of Devonian age. Organic Geochemistry, 40, 1, 1-11.

Massa, D. (1988) Paléozoïque de Libye occidentale : stratigraphie et paléogéographie. McGhee, G.R., Clapham, M.E., Sheehan, P.M., Bottjer, D.J., Droser, M.L. (2013) A new ecological-severity ranking of major Phanerozoic biodiversity crises. Palaeogeography, Palaeoclimatology, Palaeoecology, 370, 260-270.

McLennan, S.M. (1989) Rare earth elements in sedimentary rocks; influence of provenance and sedimentary processes. Reviews in Mineralogy and Geochemistry, 21, 1, 169-200.

Melendez, I., Grice, K., Trinajstic, K., Ladjavardi, M., Greenwood, P., Thompson, K. (2013) Biomarkers reveal the role of photic zone euxinia in exceptional fossil preservation: An organic geochemical perspective. Geology, 41, 2, 123-126.

Meyers, P. (1997) Organic geochemical proxies of paleoceanographic, paleolimnologic, and paleoclimatic processes. Organic Geochemistry, 27, 5/6, 213-250.

Moldowan, J.M., Dahl, J., Jacobson, S.R., Huizinga, B.J., Fago, F.J., Shetty, R., Watt, D.S., Peters, K.E. (1996) Chemostratigraphic reconstruction of biofacies: molecular evidence linking cyst-forming dinoflagellates with pre-Triassic ancestors. Geology, 24, 2, 159-162. Moldowan, J.M., Fago, F.J., Carlson, R.M.K., Young, D.C., an Duvne, G., Clardy, J., Schoell, M., Pillinger, C.T., Watt, D.S. (1991) Rearranged hopanes in sediments and petroleum. Geochimica et Cosmochimica Acta, 55, 11, 3333-3353.

Moldowan, J.M., Talyzina, N.M. (1998) Biogeochemical evidence for dinoflagellate ancestors in the Early Cambrian. Science, 281, 1168-1170.

Mongelli, G. (1995) Trace elements distribution and mineralogical composition in the $<2-\mu \mathrm{m}$ size fraction of shales from the Southern Apennines, Italy. Mineralogy and Petrology, 53, 13, 103-114.

Murphy, A.E., Sageman, B.B., Hollander, D.J., Lyons, T.W., Brett, C.E. (2000) Black shale deposition and faunal overturn in the Devonian Appalachian Basin: Clastic starvation, seasonal water-column mixing, and efficient biolimiting nutrient recycling.

Paleoceanography, 15, 3, 280-291.

Oasis oils Company (1961) D1-26 final log. 
Ourisson, G., Albrech, P., Rohmer, M. (1979) The hopanoids - Paleochemistry and biochemistry of a group of natural products. Pure and Applied Chemistry, 51, 4, 709-729. Overmann, J. (2008) Ecology of phototrophic sulfur bacteria. In : Hell, R., Dahl, C., Knaff, D., Leustek, T., (eds.). Sulfur Metabolism in Phototrophic Organisms, Springer Netherlands, Dordrecht, pp. 375-396.

Overmann, J., Cypionka, H., Pfennig, N. (1992) An extremely low-light adapted phototrophic sulfur bacterium from the Black Sea. Limnology and Oceanography, 37, 1, 150-155.

Paris, F., Nõlvak, J. (1999) Biological interpretationand paleobiodiversity of a cryptic fossil group: The "chitinozoan animal." Geobios, 32, 2, 315-324.

Peters, K.E., Walters, C.W., Moldowan, J.M. (2005) The biomarker guide, second edition. Cambridge University Press, Cambridge, 1155 p.

Peterson, L.C., Haug, G.H., Murray, R.W., Yarincik, K.M., King, J.W., Bralower, T.J., Kameo, K., Rutherford, S.D., Pearce, R.B. (2000) Late Quaternary stratigraphy and sedimentation at ODP Site 1002, Cariaco Basin (Venezuela). In : Leckie, R.M., Sigurdsson, H., Acton, G.D., Draper, G., (eds.). Proceedings of the ODP, Scientific Results, pp. 85-99. Prauss, M.L. (2007) Availability of reduced nitrogen chemospecies in photic-zone waters as the ultimate cause for fossil prasinophyte prosperity. Palaios, 22, 5, 489-499.

Racka, M., Marynowski, L., Filipiak, P., Sobstel, M., Pisarzowska, A., Bond, D.P.G. (2010) Anoxic Annulata Events in the Late Famennian of the Holy Cross Mountains (Southern Poland): Geochemical and palaeontological record. Palaeogeography, Palaeoclimatology, Palaeoecology, 297, 3, 549-575.

Racki, G. (2005) Toward understanding Late Devonian global events: few answers, many questions. In : Over, D.J., Morrow, J.R., Wignall, P.B., (eds.). Understanding Late Devonian and Permian-Triassic Biotic and Climatic Events: Towards an Integrated Approach, Elsevier, pp. 5-36.

Radke, M., Welte, D.H. (1983) The Methylphenanthrene Index (MPI): a maturity parameter based on aromatic hydrocarbons. In : Bjorøy, P., Albrecht, P., Cornford, C., (eds.). Advances in Organic Geochemistry 1981, Wiley, Chichester, pp. 504-512.

Radke, M., Willsch, H., Leythaeuser, D., Teichmüller, M. (1982) Aromatic components of coal: relation of distribution pattern to rank. Geochimica et Cosmochimica Acta, 46, 10, 1831-1848.

Requejo, A.G., Allan, J., Creaney, S., Gray, N.R., Cole, K.S. (1992) Aryl isoprenoids and diaromatic carotenoids in Paleozoic source rocks and oils from the Western Canada and Williston Basins. Organic Geochemistry, 19, 1-3, 245-264. 
Riboulleau, A., Bout-Roumazeilles, V., Tribovillard, N., Guillot, F., Recourt, P. (2014) Testing provenance diagrams: Lessons from the well-constrained Cariaco Basin. Chemical Geology, 389, 91-103.

Riquier, L., Averbuch, O., Devleeschouwer, X., Tribovillard, N. (2010) Diagenetic versus detrital origin of the magnetic susceptibility variations in some carbonate FrasnianFamennian boundary sections from Northern Africa and Western Europe: implications for paleoenvironmental reconstructions. International Journal of Earth Sciences, 99, 1, 57-73. Riquier, L., Tribovillard, N., Averbuch, O., Devleeschouwer, X., Riboulleau, A. (2006) The Late Frasnian Kellwasser horizons of the Harz Mountains (Germany): Two oxygen-deficient periods resulting from different mechanisms. Chemical Geology, 233, 1-2, 137-155. Riquier, L., Tribovillard, N., Averbuch, O., Joachimski, M.M., Racki, G., Devleeschouwer, X., El albani, A., Riboulleau, A. (2005) Productivity and bottom water redox conditions at the Frasnian-Famennian boundary on both sides of the Eovariscan Belt: constraints from traceelement geochemistry. Understanding Late Devonian And Permian-Triassic Biotic and Climatic Events Towards an Integrated Approach, Elsevier, pp. 199-224.

Romero-Sarmiento, M.-F., Riboulleau, A., Vecoli, M., Versteegh, G.J.-M. (2011) Aliphatic and aromatic biomarkers from Gondwanan sediments of Late Ordovician to Early Devonian age: An early terrestrialization approach. Organic Geochemistry, 42, 6, 605-617. de la Rue, S.R., Rowe, H.D., Rimmer, S.M. (2007) Palynological and bulk geochemical constraints on the paleoceanographic conditions across the Frasnian-Famennian boundary, New Albany Shale, Indiana. International Journal of Coal Geology, 71, 1, 72-84. Sandberg, C.A., Morrow, J.R., Ziegler, W. (2002) Late Devonian sea-level changes, catastrophic events, and mass extinctions. In : Koeberl, C., MacLeod, K.G., (eds.). Catastrophic Events and Mass Extinctions: Impacts and Beyond, Geological Society of America, p.

Schieber, J., Lazar, R.O. (2004) Devonian black shales of the eastern U.S.: New insights into sedimentology and stratigraphy from the subsurface and outcrops in the Illinois and Appalachian Basins. Indiana Geological Survey, Bloomington, Ind., 90 p.

Schwark, L., Empt, P. (2006) Sterane biomarkers as indicators of palaeozoic algal evolution and extinction events. Evolution of the System Earth in the Late Palaeozoic: Clues from Sedimentary Geochemistry, 240, 1, 225-236.

Schwark, L., Frimmel, A. (2004) Chemostratigraphy of the Posidonia Black Shale, SWGermany: II. Assessment of extent and persistence of photic-zone anoxia using aryl isoprenoid distributions. Chemical Geology, 206, 3-4, 231-248. 
Sephton, M.A., Looy, C.V., Veefkind, R.J., Visscher, H., Brinkhuis, H., de Leeuw, J.W. (1999) Cyclic diaryl ethers in a Late Permian sediment. Organic Geochemistry, 30, 4, $267-$ 273.

Soua, M. (2014) Paleozoic oil/gas shale reservoirs in southern Tunisia: An overview. Journal of African Earth Sciences, 100, 450-492.

Spina, A., Vecoli, M., Riboulleau, A., Clayton, G., Cirilli, S., Di Michele, A., Marcoguiseppe, A., Rettori, R., Sassi, P., Servais, T., et al. (2017) Assessment of thermal maturity of organic matter of Lower Palaeozoic rocks (Ghadamis Basin, North Africa): application of Palynomorph Darkness Index (PDI) and other thermal maturity indicators. Perugia-Italy,. Steemans, P. (1999) Paléodiversification des spores et des cryptospores de l'Ordovicien au Dévonien inférieur. Geobios, 32, 2, 341-352.

Streel, M. (2009) Upper Devonian miospore and conodont zone correlation in western Europe. Geological Society, London, Special Publications, 314, 1, 163.

Strother, P.K. (1991) A classification schema for the cryptospores. Palynology, 15, 1, 219236.

Summons, R.E., Powell, T.G. (1986) Chlorobiaceae in Palaeozoic seas revealed by biological markers, isotopes and geology. Nature, 319, 6056, 763-765.

Tappan, H.N. (1980) The paleobiology of plant protists. W. H. Freeman,. Taylor, T.N., Taylor, E.L., Krings, M. (2009) Paleobotany: The Biology and Evolution of Fossil Plants. Academic Press, 1230 p.

Tribovillard, N. (2013) The Ge/Si ratio as a tool to recognize biogenic silica in chert. Comptes Rendus Geoscience, 345, 3,160-165.

Tribovillard, N., Averbuch, O., Devleeschouwer, X., Racki, G., Riboulleau, A. (2004) Deepwater anoxia over the Frasnian-Famennian boundary (La Serre, France): a tectonically induced oceanic anoxic event? Terra Nova, 16, 5, 288-295.

Tribovillard, N., Bout-Roumazeilles, V., Algeo, T., Lyons, T.W., Sionneau, T., MonteroSerrano, J.C., Riboulleau, A., Baudin, F. (2008) Paleodepositional conditions in the Orca Basin as inferred from organic matter and trace metal contents. Marine Geology, 254, 1-2, $62-72$.

Tulipani, S., Grice, K., Greenwood, P.F., Haines, P.W., Sauer, P.E., Schimmelmann, A., Summons, R.E., Foster, C.B., Böttcher, M.E., Playton, T., et al. (2015) Changes of palaeoenvironmental conditions recorded in Late Devonian reef systems from the Canning Basin, Western Australia: A biomarker and stable isotope approach. Gondwana Research, 28, $4,1500-1515$. 
Tyson, R.V. (1995) Sedimentary organic matter. Chapman \& Hall, London., 615 p. Ulmishek, G.F., Klemme, H.D. (1990) Depositional controls, distribution, and effectiveness of world petroleum source rocks.

Underdown, R., Redfern, J., Lisker, F. (2007) Constraining the burial history of the Ghadames Basin, North Africa: an integrated analysis using sonic velocities, vitrinite reflectance data and apatite fission track ages. Basin Research, 19, 4, 557-578. Vandenbroucke, T.R.A., Armstrong, H.A., Williams, M., Paris, F., Sabbe, K., Zalasiewicz, J.A., Nõlvak, J., Verniers, J. (2010) Epipelagic chitinozoan biotopes map a steep latitudinal temperature gradient for earliest Late Ordovician seas: Implications for a cooling Late Ordovician climate. Early Palaeozoic Palaeoenvironments, 294, 3, 202-219. Versteegh, G.J.M., Riboulleau, A. (2010) An organic geochemical perspective on terrestrialization. Geological Society, London, Special Publications, 339, 1, 11-36. Wang, T.-G., Simoneit, B.R.T. (1995) Tricyclic terpanes in Precambrian bituminous sandstone from the eastern Yanshan region, North China. Chemical Geology, 120, 1, 155170.

Wendt, J., Belka, Z. (1991) Age and depositional environment of upper devonian (early Frasnian to early famennian) black shales and limestones (Kellwasser facies) in the eastern Anti-Atlas, Morocco. Facies, 25, 1, 51-89.

Wendt, J., Kaufmann, B., Belka, Z., Klug, C., Lubeseder, S. (2006) Sedimentary evolution of a Palaeozoic basin and ridge system: the Middle and Upper Devonian of the Ahnet and Mouydir (Algerian Sahara). Geological Magazine, 143, 3, 269.

Weyant, M., Massa, D. (1991) Contribution of conodonts to the Devonian biostratigraphy of Western Libya. In : Salem, M.J., Hammuda, O.S., Eliagoubi, B.A., (eds.). The Geology of Libya, Elsevier, Amsterdam, pp. 1297-1322.

Whitaker, M.F. (1984) The usage of palynology in definition of Troll Field geology. In: Reduction of uncertainties in innovative reservoir geomodelling. 6th Offshore Northern Seas Conference and Exhibition, Norsk petroleums forenning, Stavanger, pp. 1-50.

Wilde, P., Quinby-Hunt, M.S., Erdtmann, B.-D. (1996) The whole-rock cerium anomaly: a potential indicator of eustatic sea-level changes in shales of the anoxic facies. Sedimentary Geology, 101, 1-2, 43-53.

\section{Figure captions}


Figure 1: Location map of the Ghadames Basin showing the location of borehole D1-26.

1028

1029

1030

1031

1032

1033

1034

1035

1036

1037

1038

1039

1040

1041

1042

1043

1044

1045

1046

1047

1048

1049

1050

1051

1052

1053

1054

1055

1056

1057

1058

1059

Figure 2: Lithological and stratigraphic description of the Upper Devonian formations in borehole D1-26, with sonic and resistivity (ILD) curves (unavailable scale). Compilation of data from Oasis oils Company (1961), Canaple (1963) Loboziak and Streel (1989), Weyant and Massa (1991) Spina et al. (2017). The peaks in the ILD curve (grey area) underline an alternance of shale and limestones corresponding to the radioactive shales and Cues Limestone horizon.

Figure 3: Palynofacies observations of the samples from borehole D1-26. A) Particle counting; B,C) Prasinophycean cysts, AOM and acritarchs (B: slide 7802; C: slide 7780); D) Prasinophycean cysts and AOM (slide 7704); E) miospores, Prasinophycean cysts and palynomacerals (slide 7083). Photographs show the $>50 \mu \mathrm{m}$ palynological residue. Legend of the $\log$ as in fig. 2.

Figure 4: Rock-Eval and bulk geochemistry of samples from borehole D1-26. A) Hydrogen index (HI) versus Tmax plot showing the type and maturity of the organic matter. B) Total sulfur versus total organic carbon (TOC) of the sediment. The dotted line corresponds to the relationship observed in "normal marine" shales (Berner, 1982; Berner and Raiswell, 1983). C) Same as B after doubling the TOC content in order to account for thermal loss of organic matter.

Figure 5: Mineral redox proxies in the samples from borehole D1-26. A) Enrichment factor (EF) of the main redox-sensitive trace elements. B) Cerium anomaly. The grey interval corresponds to the Cues Limestone horizon and radioactive shales.

Figure 6: Detrital proxies in the samples from borehole D1-26. A) major and trace element content normalized to the aluminum content. B) Rare earth element ratios and europium anomaly. The grey interval corresponds to the Cues Limestone horizon and radioactive shales.

Figure 7: Rare earth element content in the samples from borehole D1-26 normalized to the Post Archean Average Shale (PAAS, McLennan, 1989). 
1060 Figure 8: Representative fragmentograms showing the biomarker distribution in the aliphatic 1061 fraction of the extracts from borehole D1-26 samples. A) $n$-alkanes and linear isoprenoids 1062 (m/z 57; sample 7087). B) Di- and tri-cyclic terpenoids (m/z 123; sample 7087). C)

1063 Cheilantanes and hopanoids (m/z 191; sample 7085). D) Steroids and diasteroids (m/z 217; 1064 sample 7780). Numbers above symbols indicate carbon number.

1065

1066 Figure 9: Example of distribution of isorenieratene and palaerenieratene derivatives in the 1067 aromatic fraction of the extracts from borehole D1-26 samples (m/z 133+134; sample 7810).

1069 Figure 10: Molecular indicators of redox conditions in the extracts from D1-26 samples. A)

1070 Total concentration of isorenieratene and palaerenieratene derivatives in the extracts. B) $\mathrm{C}_{16^{-}}$

$1071 \mathrm{C}_{31}$ palaerenieratene to isorenieratene derivatives ratio (PIR). The grey interval corresponds to 1072 the Cues Limestone horizon and radioactive shales. C) Pristane to phytane ratio ( $\mathrm{Pr} / \mathrm{Ph})$ versus 1073 the modified aryl isoprenoid ratio (AIR*). Scheme from Schwark and Frimmel (2004)

Figure 11: Depositional model for organic matter in the Ghadames Basin during the Frasnian to upper Famennian interval. See text for explanations.

\section{Supplementary material}

1079 Table S1: major, trace and rare earth element content in samples from borehole D1-26. 


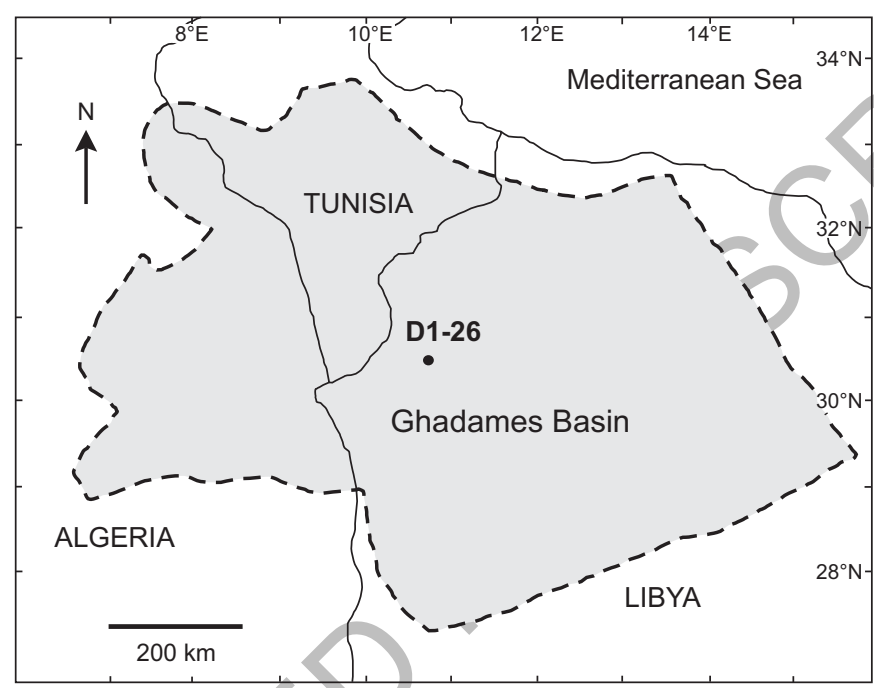

Figure 1 


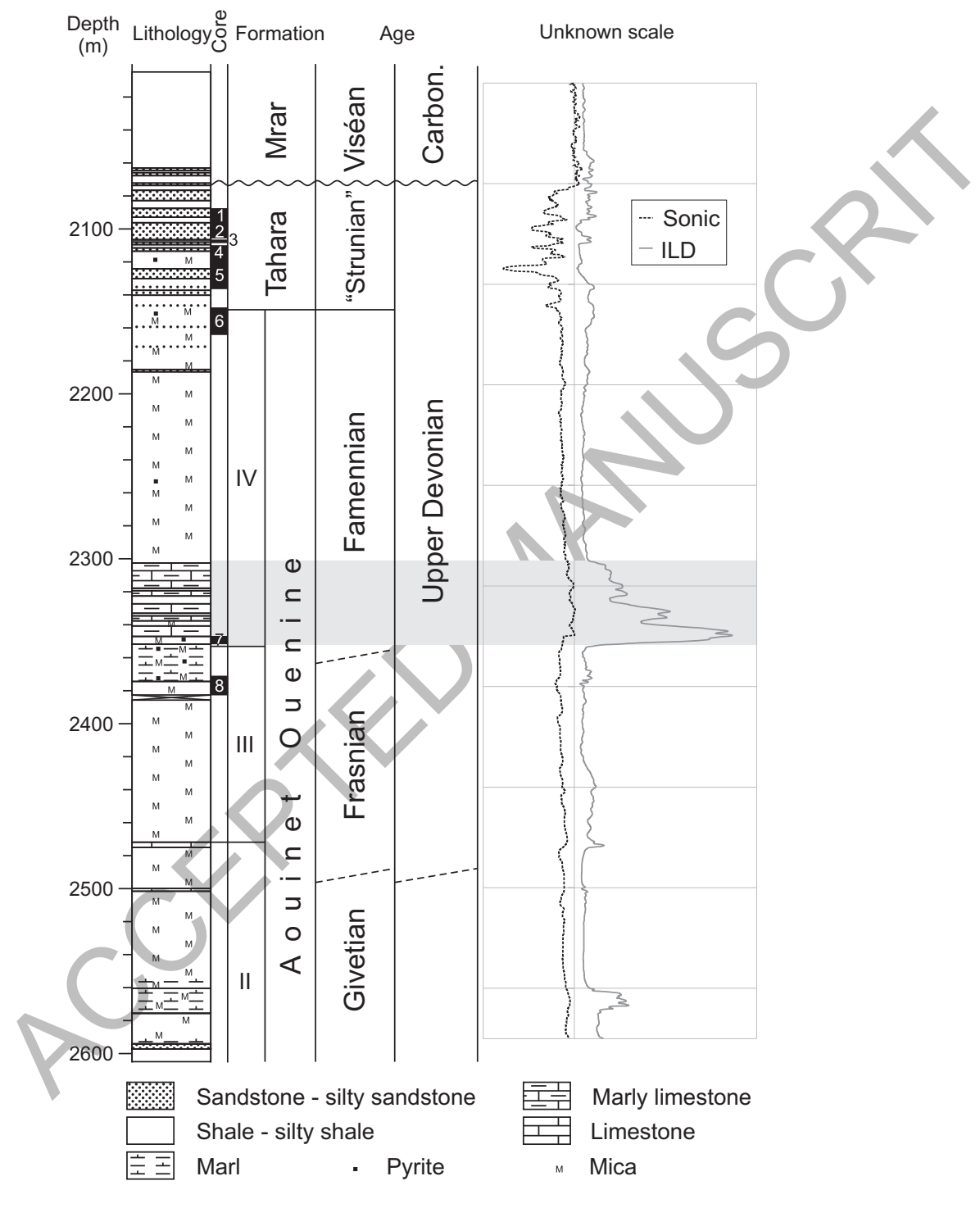

Figure 2 


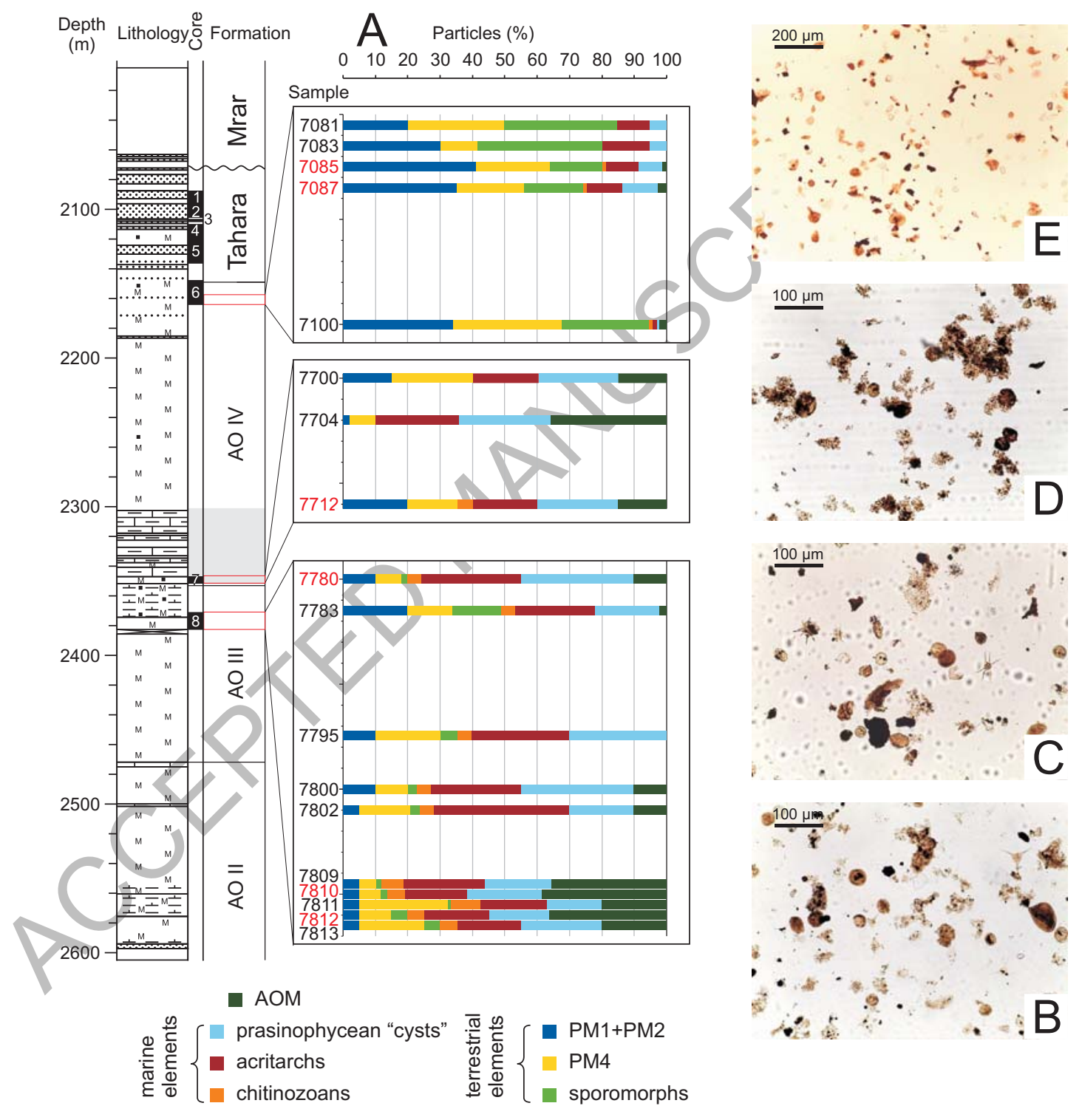

Figure 3 

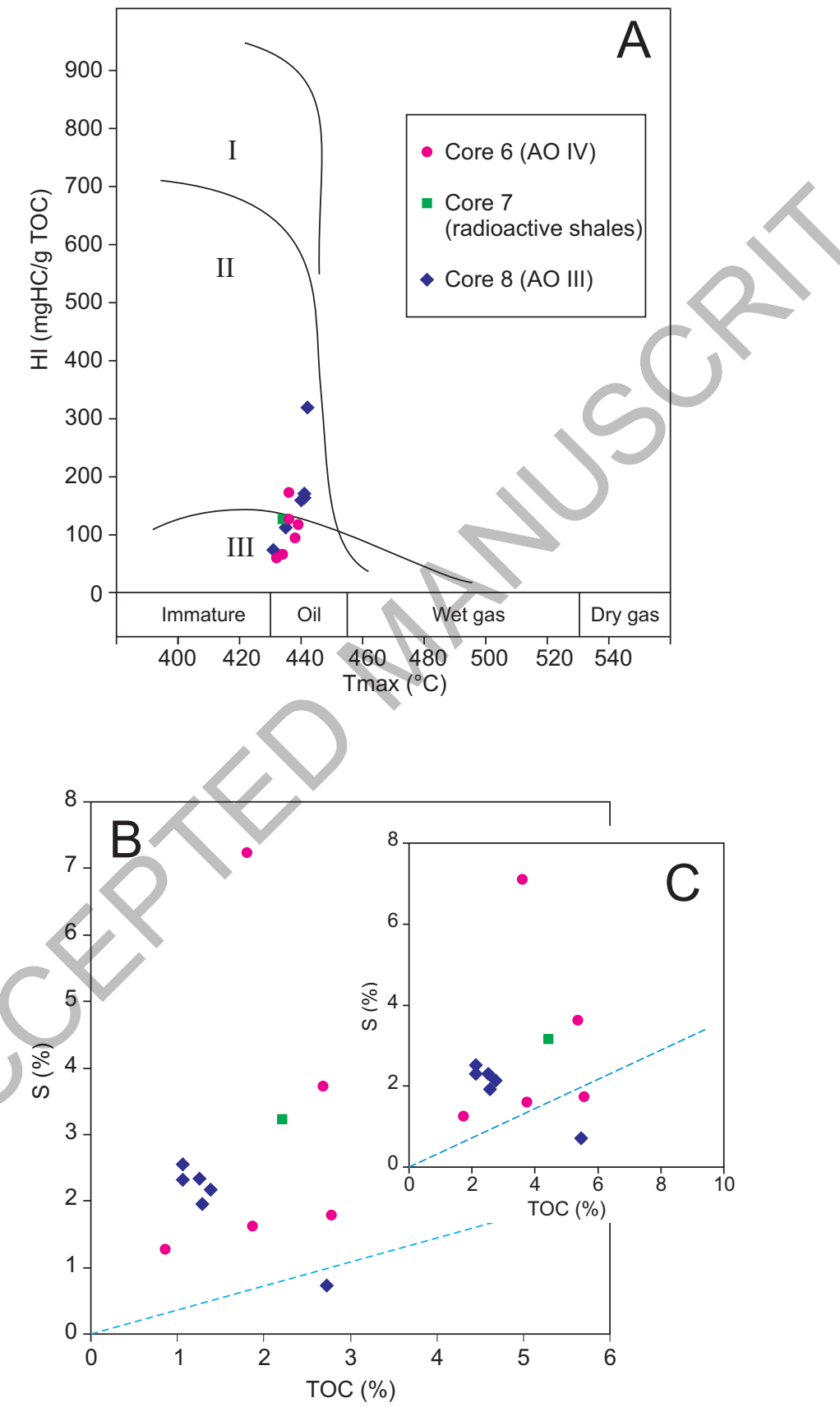

Figure 4 

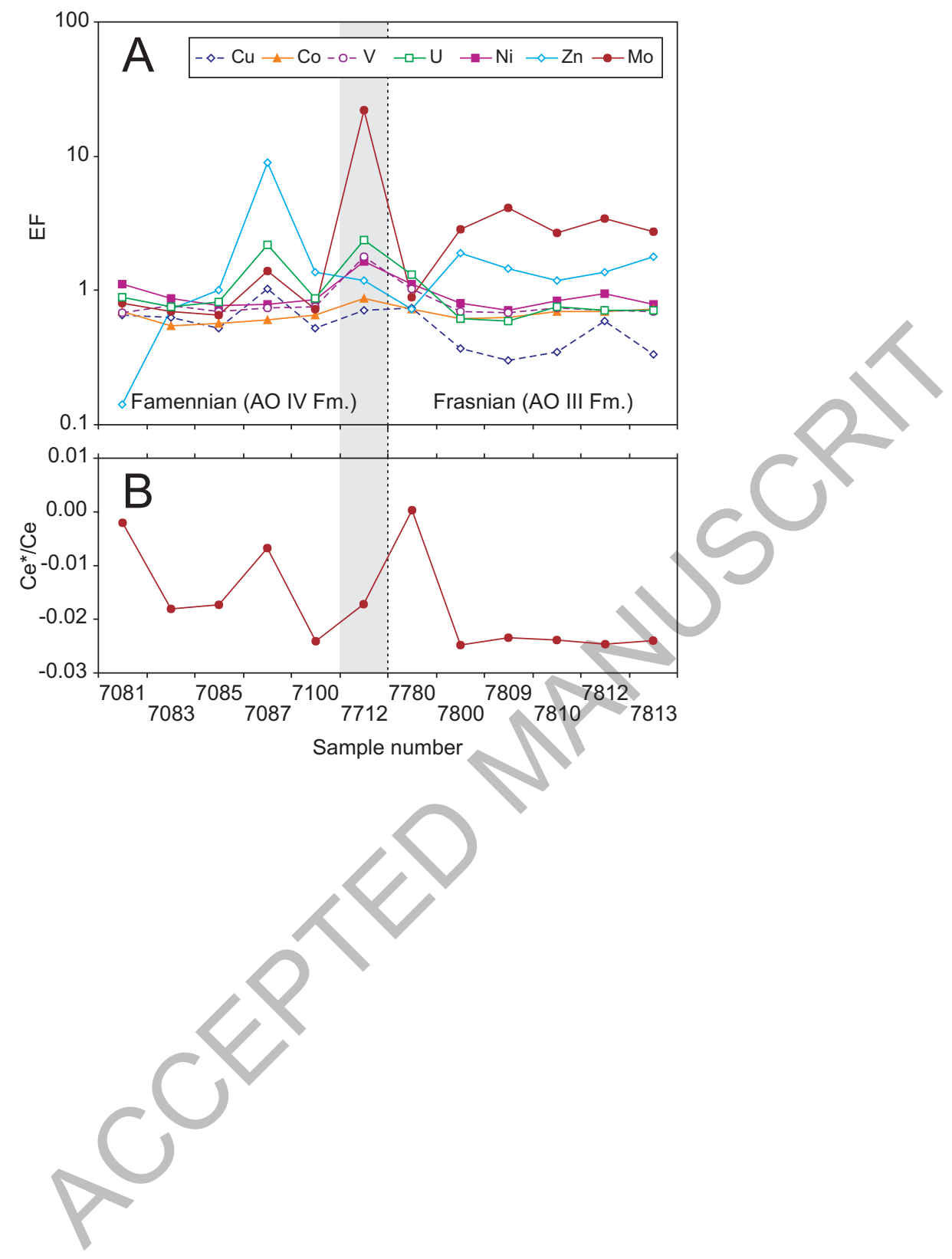

Figure 5 

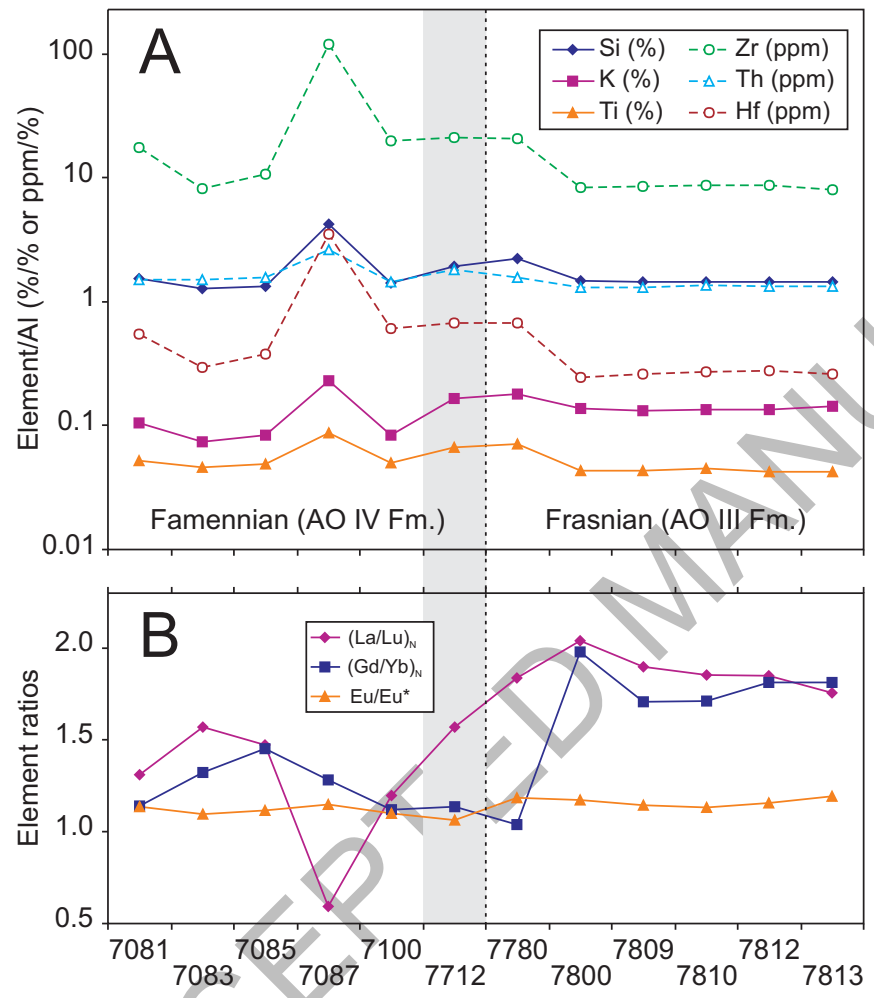

Sample number 

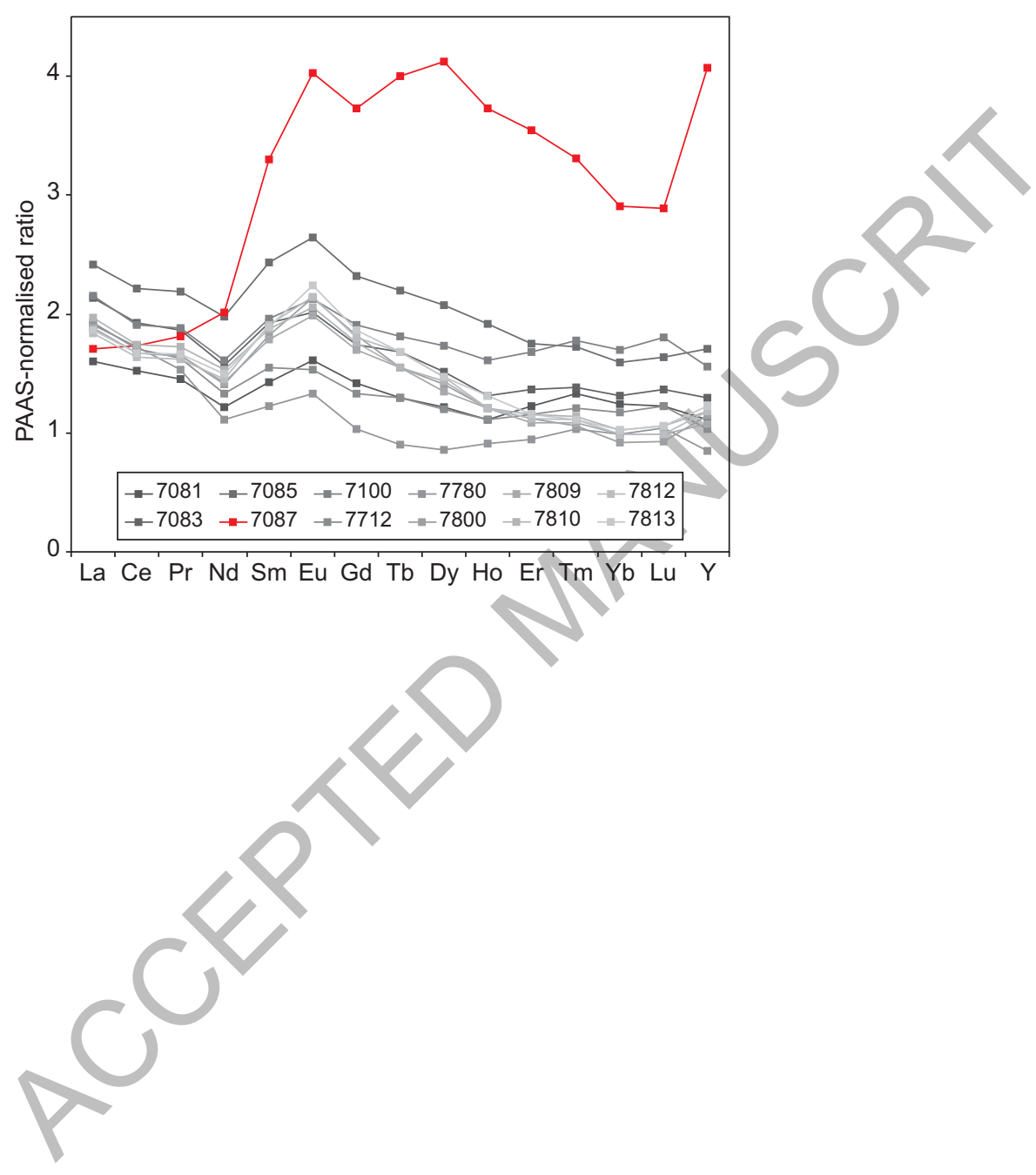

Figure 7 


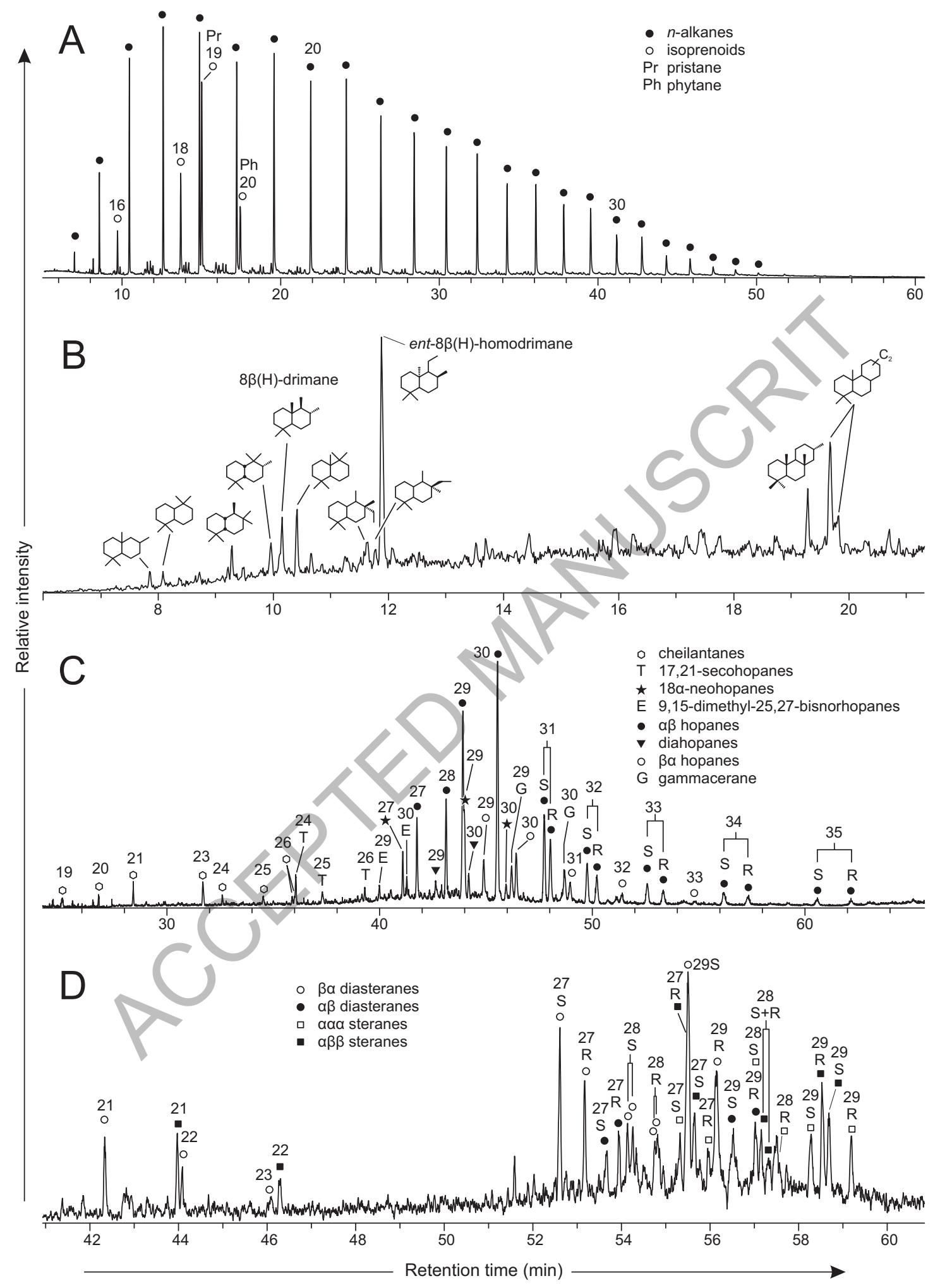

Figure 8 


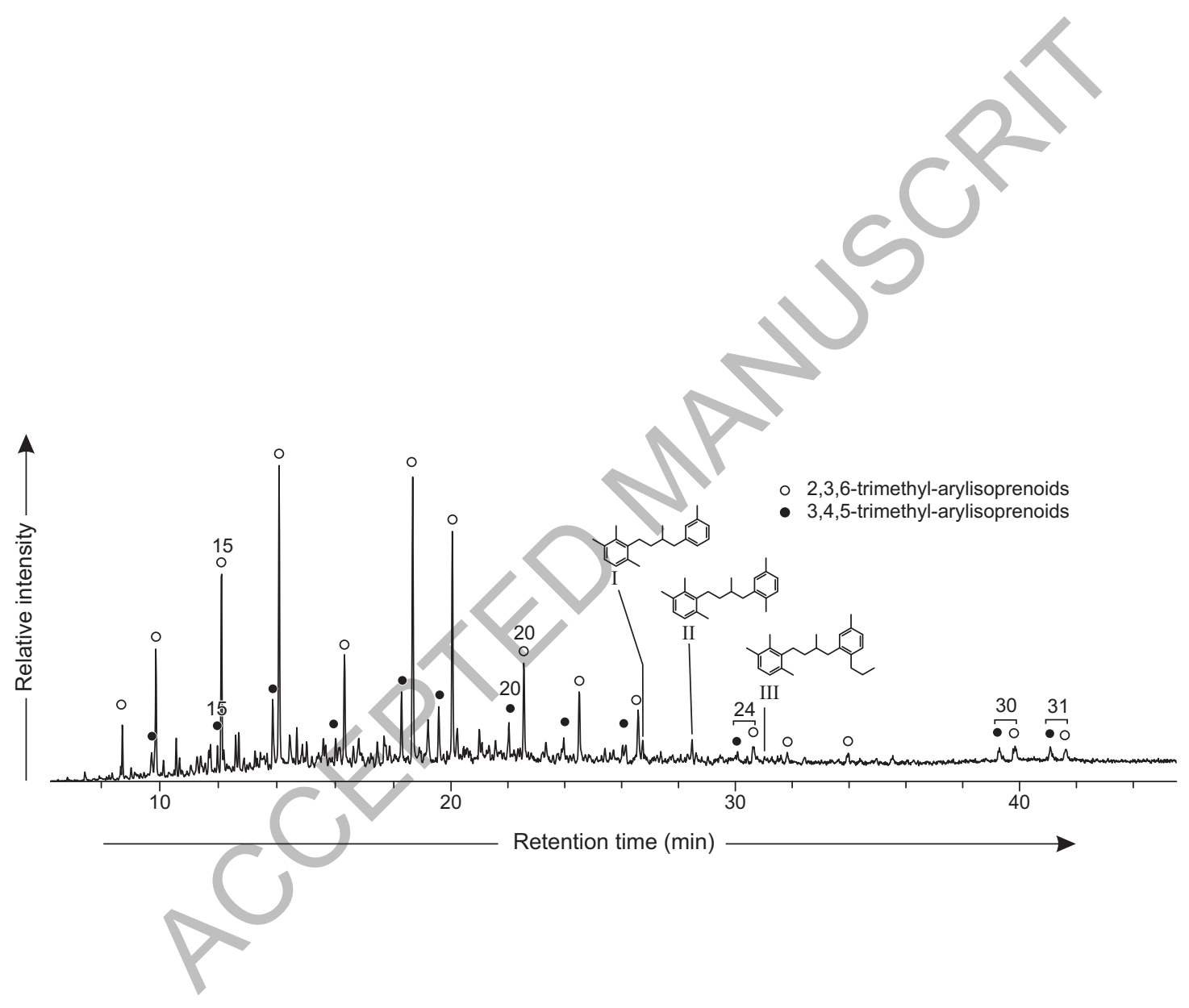

Figure 9 

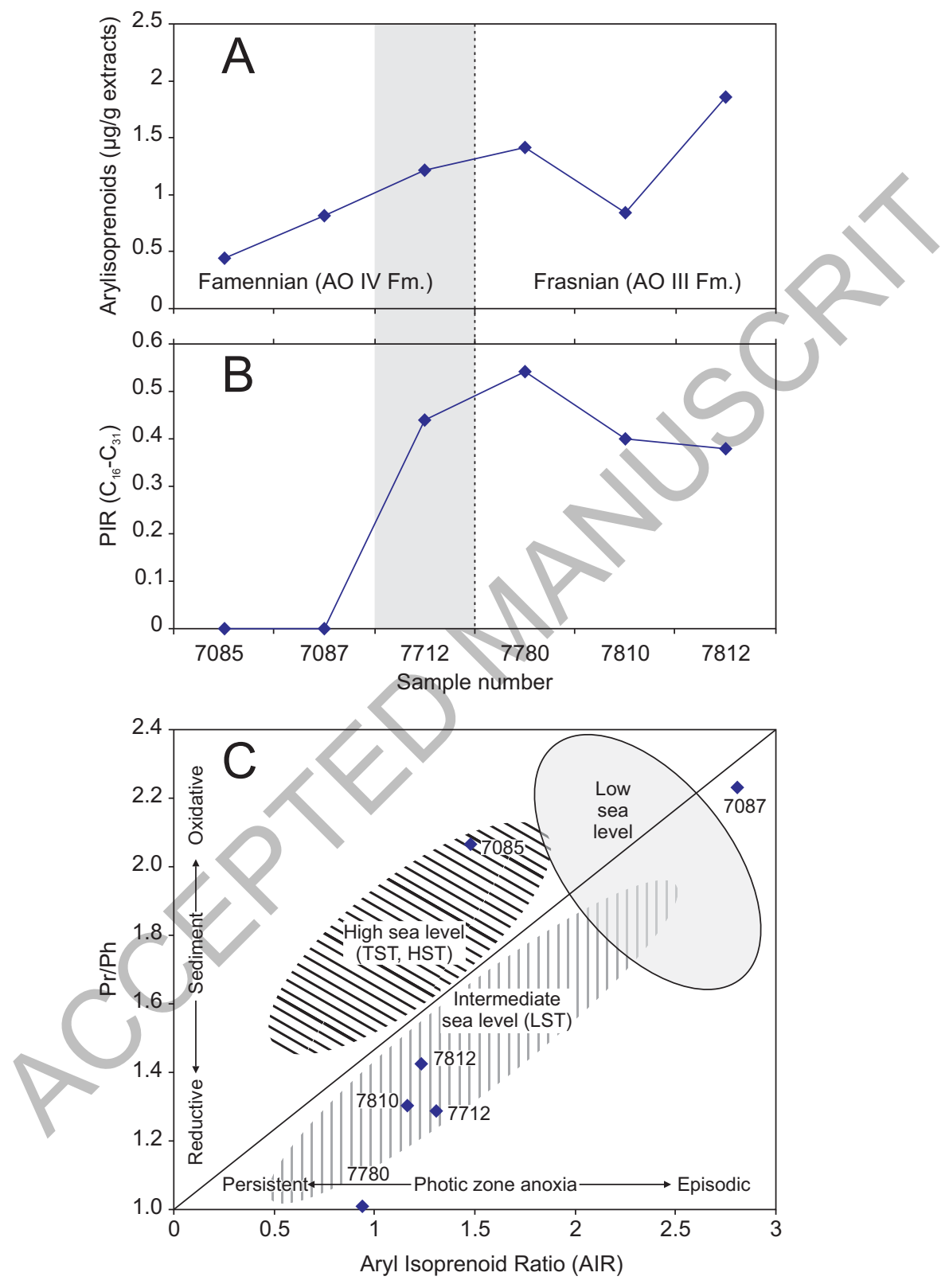

Figure 10 

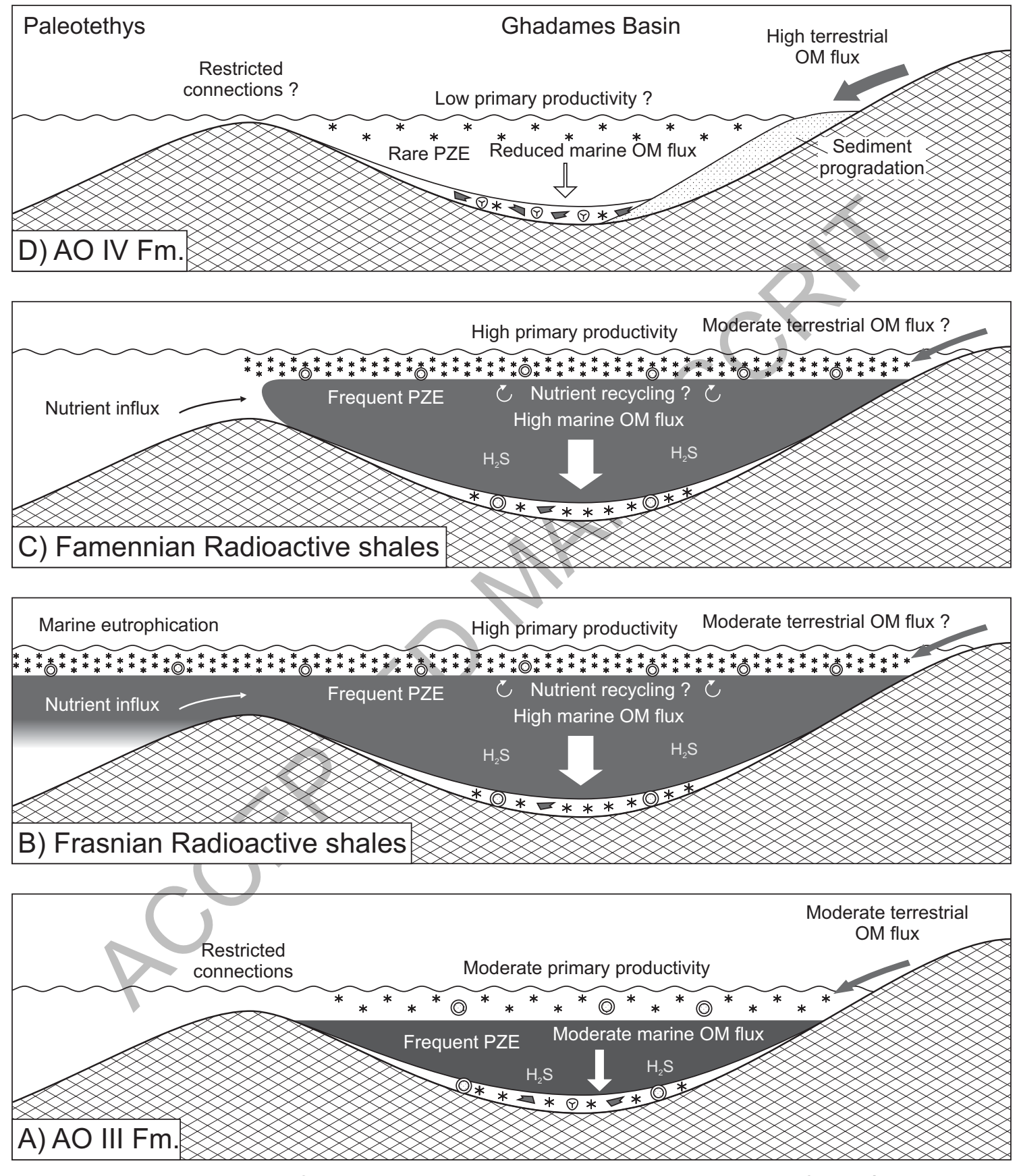

PZE Photic-zone euxinia $\otimes$ Sporomorphs $\quad$ Palynomacerals * Acritarchs and AOM $\bigcirc$ Tasmanites 


\section{Tables}

Table 1: Rock Eval and elemental analysis results of the samples from borehole D1-26.

$\begin{array}{lccccccccccc}\text { Sample } & \mathrm{S}^{1} & \mathrm{~S}{ }^{1}{ }^{1} & \begin{array}{c}\mathrm{Tmax} \\ { }^{\circ} \mathrm{C}\end{array} & \begin{array}{c}\mathrm{TOC} \\ \%\end{array} & \mathrm{PI}^{2} & \mathrm{HI}^{3} & \mathrm{OI}^{4} & \begin{array}{c}\mathrm{C}_{\min } \\ (\%)\end{array} & \begin{array}{c}\mathrm{S} \\ (\%)\end{array} & \begin{array}{c}\mathrm{N} \\ (\%)\end{array} & \begin{array}{c}\mathrm{TOC} / \mathrm{N} \\ 7081\end{array} \\ & 0.19 & 1.08 & 432 & 1.8 & 0.15 & 60 & 0 & 0.1 & 7.23 & 0.06 & 35 \\ 7083 & 0.24 & 1.78 & 434 & 2.68 & 0.12 & 66 & 0 & 0.14 & 3.73 & 0.08 & 39 \\ 7085 & 0.36 & 3.53 & 436 & 2.78 & 0.09 & 127 & 8 & 0.12 & 1.79 & 0.08 & 41 \\ 7087 & 0.15 & 1.01 & 439 & 0.86 & 0.13 & 117 & 48 & 0.96 & 1.27 & 0.03 & 33 \\ 7100 & 0.2 & 1.76 & 438 & 1.87 & 0.1 & 94 & 22 & 0.86 & 1.63 & 0.05 & 44 \\ 7712 & 0.85 & 2.8 & 434 & 2.21 & 0.23 & 127 & 5 & 0.16 & 3.23 & 0.12 & 21 \\ 7780 & 1.55 & 8.7 & 442 & 2.73 & 0.15 & 319 & 2 & 0.14 & 0.73 & 0.13 \\ 7800 & 0.7 & 0.77 & 431 & 1.06 & 0.48 & 73 & 27 & 0.13 & 2.55 & 0.07 \\ 7809 & 0.65 & 1.19 & 435 & 1.06 & 0.35 & 112 & 0 & 0.05 & 2.32 & 0.09 \\ 7810 & 0.78 & 2.2 & 441 & 1.29 & 0.26 & 171 & 12 & 0.09 & 1.95 & 0.1 \\ 7812 & 0.86 & 2.05 & 441 & 1.26 & 0.29 & 163 & 0 & 0.1 & 2.33 & 0.09 \\ 7813 \\ 1\end{array}$


Table 2: Biomarker ratios in the extracts of samples from borehole D1-26.

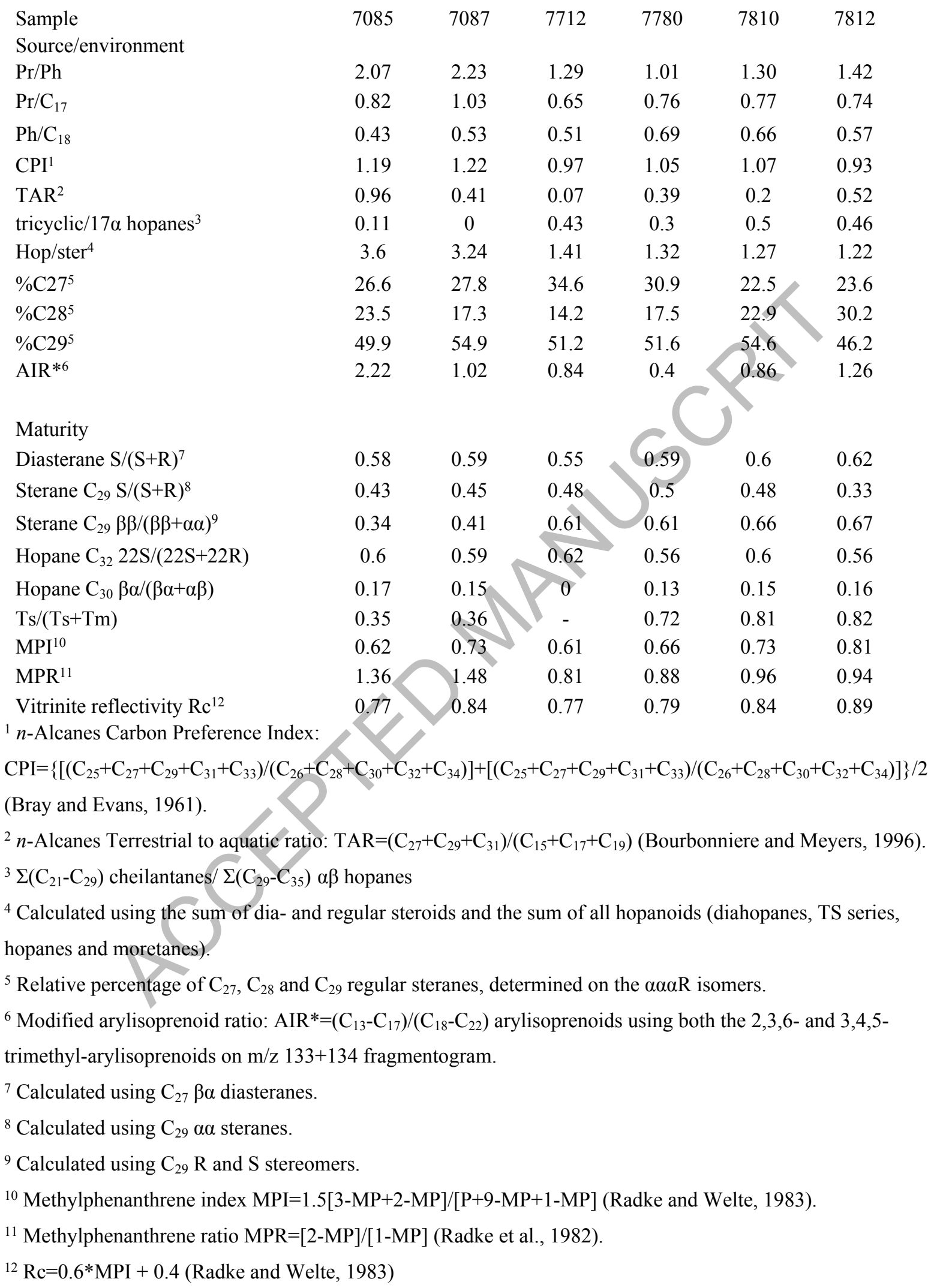




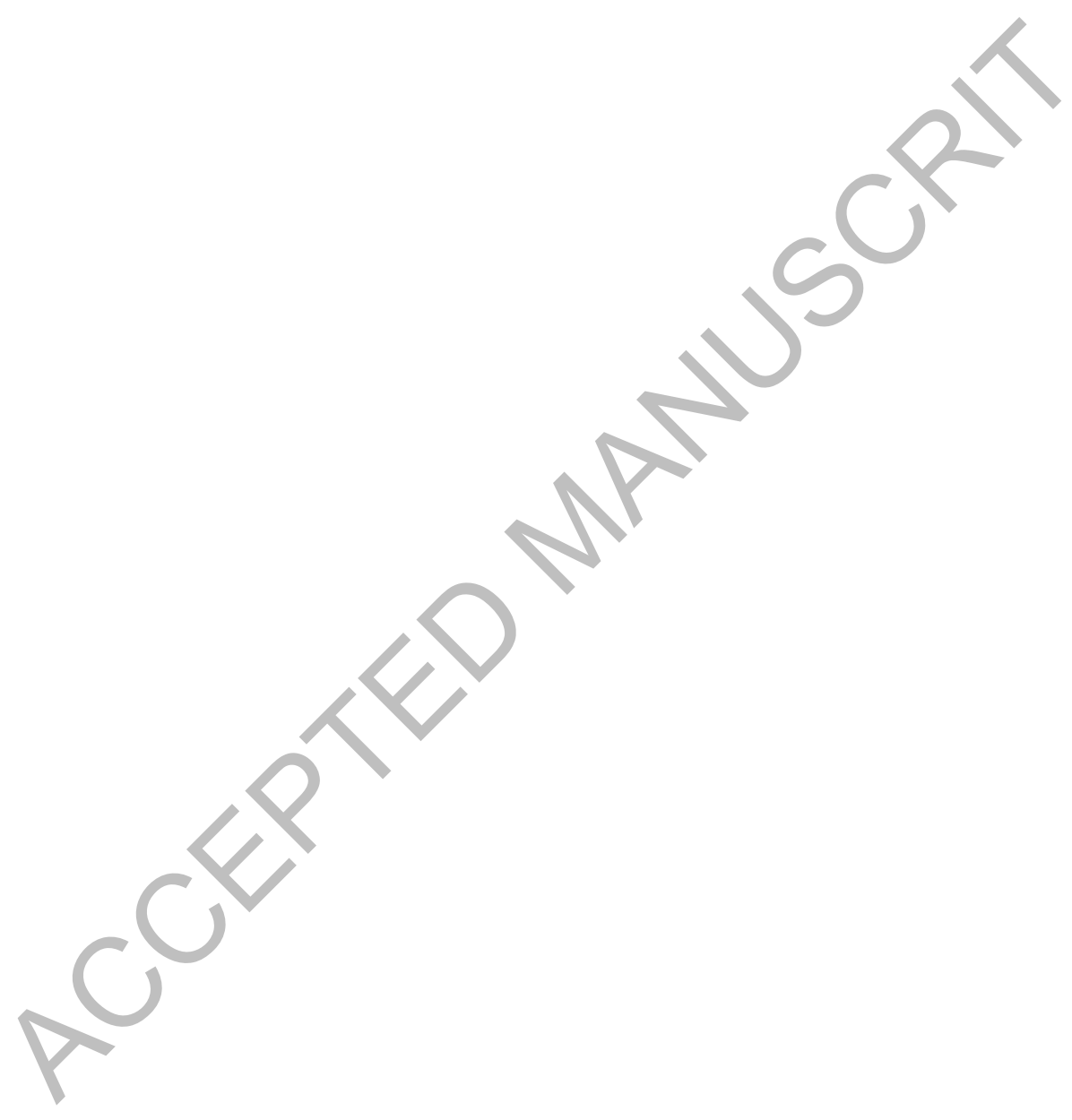

